Florida International University FIU Digital Commons

\title{
Defending the double monastery: aldhelm of Malmesbury's de Virginitate and seventh-century England
}

Thomas Cramer

Florida International University

DOI: $10.25148 /$ etd.FI14061538

Follow this and additional works at: https://digitalcommons.fiu.edu/etd

Part of the History of Religion Commons, and the Medieval History Commons

\section{Recommended Citation}

Cramer, Thomas, "Defending the double monastery: aldhelm of Malmesbury's de Virginitate and seventh-century England" (2001). FIU Electronic Theses and Dissertations. 2718.

https://digitalcommons.fiu.edu/etd/2718 


\section{FLORIDA INTERNATIONAL UNIVERSITY}

Miami, Florida

DEFENDING THE DOUBLE MONASTERY:

ALDHELM OF MALMESBURY'S DE VIRGINITATE AND SEVENTH-CENTURY

ENGLAND

A thesis submitted in partial fulfillment of the

requirements for the degree of

MASTER OF ARTS

in

HISTORY

by

Thomas Cramer

2001 
This thesis, written by Thomas Cramer, and entitled Defending the Double Monastery: Aldhelm of Malmesbury's De Virginitate and Seventh-Century England, having been approved in respect to style and intellectual content, is referred to you for judgment.

We have read this thesis and recommend that it be approved.

Hugh Thomas

Hugh Elton

Felice Lifshitz, Major Professor

Date of Defense: August 2, 2001

The thesis of Thomas Cramer is approved.

Dean Arthur W. Herriott College of Arts and Sciences

Dean Douglas Wartzok

Graduate School

Florida International University, 2001 


\section{ABSTRACT OF THE THESIS}

\section{DEFENDING THE DOUBLE MONASTERY:}

\section{ALDHELM OF MALMESBURY'S DE VIRGINITATE IN SEVENTH-CENTURY \\ ENGLAND}

by

Thomas Cramer

Florida International University, 2001

Miami, Florida

Professor Felice Lifshitz, Major Professor

The double monasteries of seventh-century England have long been a problematic institution for historical interpretation. The purpose of this project is an attempt to place these institutions in relation to the ecclesiastical controversies of seventh-century England. Archbishop Theodore, who wished to reform the Anglo-Saxon church, challenged the role of the double monasteries. The attack on the double monasteries was instituted along gendered lines by evoking religious traditions that called into question the legitimacy of cooperation between monastic men and women. However, this position was not universally accepted. Aldhelm of Malmesbury's De Virginitate provides a theological defense for the double monastery by constructing a competing notion of 
gender relations that emphasized cooperative relationships. The conclusions of this study show that there were competing conceptions of gender relations in seventh-century

England and that active cooperation between the sexes in a monastic environment was sometimes considered to be possible, and even preferable. 
ONE. 1

Historiographical Issues.................................................... 8

The 'Male Element' in the Double Monasteries................................ 13

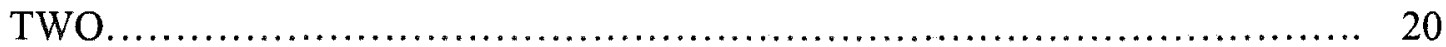

Structure and Function of the Double Monastery............................ 23

Authority and the Double Monastery........................................ 29

Challenge.................................................................. 38

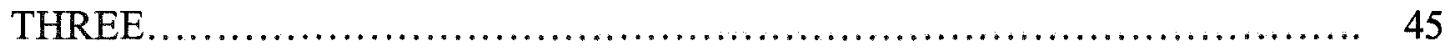

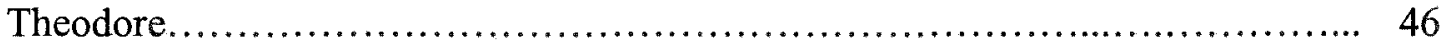

John Chrysostom....................................................... 48

Paul and Augustine..................................................... 52

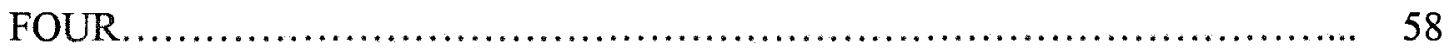

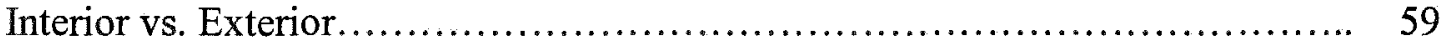

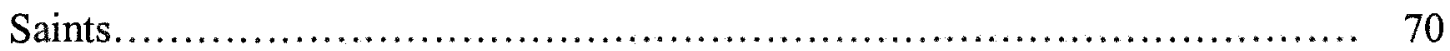

Spiritual Marriage.......................................................... 74

Conclusion ............................................................. 79

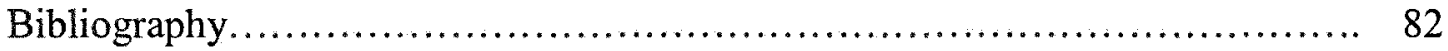




\section{Chapter 1}

Aldhelm of Malmesbury (639 - 710) was widely regarded as one of the leading scholars of the seventh century. An influential member of society who served as the abbot of Malmesbury and later the bishop of Sherborne, Aldhelm is primarily known for his intricate Latin style and his poetic works. ${ }^{1}$ Over the past generation increasing attention to his work by scholars has rectified a long period of neglect for a man who had an immense influence upon both Anglo-Saxon and Continental culture. Much of this consideration has focused on the literary influence of Aldhelm's style and form. Frank Stenton has argued that while Aldhelm's "curiously involved and artificial Latin style" was often imitated, it obfuscated the content to make it largely incomprehensible and therefore of negligible impact. More recent treatments of Aldhelm's work have also focused primarily upon the stylistic elements of Aldhelm's text at the expense of the specific content of his work. ${ }^{2}$ Andy Orchard has argued that "Aldhelm's prose style can be described as a triumph of form over content." However, I would suggest that there is much more to Aldhelm's work than merely "rhetorical pyrotechnics." 3

This study will specifically address Aldhelm's De Virginitate, within the context

\footnotetext{
${ }^{1}$ Andy Orchard, The Poetic Art of Aldhelm, Cambridge Studies in Anglo-Saxon England; 8 (Cambridge, England; New York: Cambridge University Press, 1994). Frank Stenton, Anglo-Saxon England, 3d ed. (Oxford: Clarendon Press, 1971), 178.

${ }^{2}$ For example Michael Lapidge and Michael Herren, ed. Aldhelm: The Prose Works (Cambridge: 1979). Orchard, The Poetic Art of Aldhelm. Michael Winterbottom, "Aldhelm's Prose Style and Its Origins," Anglo-Saxon England, no. 6 (1977), 39-76. A significant exceptions to this trend is Stephanie Hollis, Anglo-Saxon Women and the Church: Sharing a Common Fate (Woodbridge, Suffolk UK ; Rochester, NY: Boydell Press, 1992).

${ }^{3}$ Orchard, The Poetic Art of Aldhelm, 11, 15.
} 
of the religious and social controversies of seventh-century Anglo-Saxon England. ${ }^{4}$

While the focus of my project will be on establishing a plausible historical interpretation of the De Virginitate, the implications of the research speak to much broader issues. Specifically, this thesis will attempt to contribute to an understanding of the tensions between the conflicted conceptions of gender that were present within the ecclesiastical discourse and the social and political contexts that informed them. Furthermore, the result of this analysis will then be examined for the ways in which they were applied to the double monastery.

The double monastery, where monks and nuns lived in the same community and were ruled by an abbess, ${ }^{5}$ has proven to be a problematic institution for historical interpretation. It is a topic that has only recently returned to any prominence in medieval studies. ${ }^{6}$ The double monastery and the De Virginitate are explicitly linked as Aldhelm

\footnotetext{
${ }^{4}$ The De Virginitate is part of a long tradition of early Christian literature on this subject. Aldhelm's De Virginitate is an opus geminatum that covers the same subject in separate works of prose and verse. I have chosen to focus my research upon the prose version as it seems to be the earlier of the two compositions and it is more directly oriented towards the issues that I intend to address. The modern edition of the $D e$ Virginitate is edited by Rudolf Ehwald, ed. Monumenta Germaniae Historica. Auctores antiquissimi; t. 15 Aldhelmi Opera (Berlin: Weidman, 1919); translated into English by Lapidge and Herren, eds. Prose Works. All English translations of the De Virginitate will come from this source unless otherwise noted. ${ }^{5}$ The definition of what precisely constitutes a double monastery has been an area of long standing debate. For a full description of the derivation of the scholarly adaptation of the term double monastery see Catherine Peyroux, "Abbess and Cloister: Double Monasteries in the Early Medieval West" (Dissertation, Princeton University, 1991), 4-18. The term itself, monasterium duplex is rarely found in contemporary sources but seems to have entered into scholarly usage in Jean Mabillon's Acta Sanctorum Ordinis Sancti Benedicti Paris: 1668-1701; Venice 1733-1738.

${ }^{6}$ c.f. Mary Bateson, "The Origin and Early History of Double Monasteries," Transactions of the Royal Historical Society 13 (1899), 137-198. Alexander Thompson, "The Ministry of Women: A Report by a Committee Appointed by His Grace, the Lord Archbishop of Canterbury with Appendices and Fifteen Collotype Illustrations," ed. Archbishop of Canterbury's Committee on the Ministry of Women (London: Society for Promoting Christian Knowledge, 1919), 145-164. While the earlier focus upon double monasteries was prompted in many ways by nationalistic religious controversies, the modern emphasis has arisen out of feminist scholarship concerned with the powerful roles occupied by the abbesses. e.g. For an example from the nineteenth c. see Pierre Joseph Varin, "Mémoire sur les causes de la dissidence entre l'Église Romaine, relativement à la célébration de la fête de Pâques." Mémoires présentés par divers savants a l'Académie de Inscriptions et Belles-Lettres, 1, 5: 88-243. Paris: 1858. A recent example in this
} 
states that the De Virginitate was written in reply to a request sent from a double

monastery at Barking. Further, he was clearly aware of the conditions at the double monastery and the treatise is addressed to individual members of this double monastery. ${ }^{7}$ Perhaps the most salient aspect of the De Virginitate is that Aldhelm appears to have been using the work to provide a theological defense for the double monastery.

The necessity of such a defense arose from the influx of Mediterranean religious culture which was establishing authority in the region. The focal point for this movement was the new Archbishop of Canterbury, Theodore of Tarsus. He arrived in Anglo-Saxon England in 669 and held the position until his death in 690 . Theodore himself was a Cilician exile from the Arab invasions and was steeped in the eastern traditions where both imperial and conciliar judgments had a long history of opposing the association of male and female monastics. ${ }^{8}$ It is therefore not surprising that as part of his program to establish the "true and orthodox faith" Theodore declared that monastic men and women were forbidden to live in the same household. ${ }^{10}$ While he was apparently willing to defer enforcing this judgment due to the prominent place that double monasteries held in Anglo-Saxon society, it is clear that this particular ecclesiastical authority did not view

vein is from Suzanne Fonay Wemple, Women in Frankish Society: Marriage and the Cloister, 500 to 900 (Philadelphia: University of Pennsylvania Press, 1981).

${ }^{7}$ Lapidge and Herren, eds. Prose Works, 52.

${ }^{8}$ At least six church councils in the fourth century opposed the association of monks and nuns, most notably the Council of Nicaea in 325 . Perhaps the most influential individual voice for speaking out against syncretism was that of John Chrysostom of Antioch. e.g. Adversus eos qui subintroductas habent virgines translated into English in Elizabeth Clark, "Instruction and Refutation Directed against Those Men Cohabitating with Virgins." in Jerome, Chrysostom, and Friends: Essays and Translations. (Toronto: Edwin Mellen Press, 1979), 158-248.

${ }^{9}[H]$ istoria $[$ E]cclesiastica IV.17 fidem rectam et orthodoxam exposuimus.

${ }^{10}$ Poenitentiale Theodori II.vi.8 Paul Finsterwalder, ed. Die Canones Theodori Cantuariensis und ihre Überlieferungsformen. (Weimar: Hermann Böhlaus Nachfolger G. m. b. H, 1929). Translated by John McNeil and Helena M. Gamer, eds. Medieval Handbooks of Penance: A translation of the principal libri poententiales and selections from related documents. (New York: Columbia University Press, 1990), 204. 
the arrangement in a favorable light. As an abbot of a prestigious monastery who had been personally trained in Theodore's school, ${ }^{11}$ Aldhelm himself was associated with this Roman hierarchy and would have been expected to uphold the orthodox stance.

The De Virginitate is very difficult to date precisely. ${ }^{12}$ There are four points upon which a date might be based. First, Aldhelm mentions that he is going to an episcopal convention - conciliabulum - when he first received the request from Barking for the De Virginitate. ${ }^{13}$ We know that Aldhelm attended at least one such council from his letter to King Geriant ${ }^{14}$ and the issues described in this letter match most of what we know of the Council of Hertford in 672. ${ }^{15}$ However, Aldhelm may have attended many councils during the course of his career and so this can not be used to specifically date the $D e$ Virginitate.

Rudolf Ehwald suggested a date sometime after 685 owning to the presence of Cuthburg at Barking. Cuthburg was married to King Aldfrith of Northumbria (685-705) but later divorced him and founded the monastery at Wimbourne. ${ }^{16} \mathrm{He}$ argues that since she was present at Barking the De Virginitate must be dated sometime after 685 .

However, Lapidge and Herren has argue that this dating is untenable due to the fact that we do not know either when Cuthburg married Aldfrith or when they divorced. ${ }^{17}$ As it

\footnotetext{
${ }^{11}$ Aldhelmi et ad Aldhemvfm Epistvlae 2 Ehwald, ed. Opera, 478.

${ }^{12}$ The best discussion of the issues regarding the dating of the De Virginitate can be found in Lapidge and Herren, eds. Prose Works, 14-15.

${ }^{13}$ De Virginitate I.1

${ }^{14}$ Aldhelmi et ad Aldhelmi Epistulae Rudolf Ehwald, ed. Aldhelmi Opera (Berlin: Weidmar, 1919), 475. 503. Nuper cum essem in concilio episcoporum

${ }^{15}$ c.f. $H E$ IV. 5

${ }^{16}$ Anglo-Saxon Chronicle 718 Charles Plummer, ed. Two of the Saxon Chronicles Parallel (Oxford: Clarendon, 1892), 718.

${ }^{17}$ Lapidge and Herren, Prose Works, 14
} 
might have been before or after he ascended to the throne we cannot use her presence for dating the De Virginitate.

The final two points for dating the De Virginitate come from Aldhelm's correspondence. A letter from Cellanus, abbot of Pèronne in northern France, refers to Aldhelm as an abbot and mentions having read Aldhelm's "books which were painted with the charms of various flowers." ${ }^{18}$ This is reminiscent of Aldhelm's own description of the De Virginitate where he describes it as "plucking crimson flowers of modesty from the meadows of holy books." 19 The books mentioned by Cellanus are probably the $D e$ Virginitate and we could then date the composition of the De Virginitate at sometime between the dates of his abbacy - 673-705.

Finally, in a letter to Heahfrith, a young student of his, Aldhelm repeats four lines from the Carmen De Virginitate. ${ }^{20}$ This letter mentions Theodore as being alive and therefore must have been written before Theodore's death in 690 . The problem in associating the lines from this letter with the De Virginitate is that it is not certain which was written first. As Lapidge and Herren have argued, "Aldhelm may well have re-cycled in his De Virginitate four lines which he had earlier composed for inclusion in his letter to Heahfrith." ${ }^{21}$ While this evidence cannot be used to precisely date the De Virginitate, the weight of the evidence would suggest that it was composed sometime after Theodore's arrival in 669.

There are three key characteristics of the treatise that have caused particular difficulty in interpreting the De Virginitate: Aldhelm's use of both male and female

\footnotetext{
${ }^{18}$ Ehwald, ed. Opera, 498-499. archimandritae fastos diversorum deliciis florum depictos

${ }^{19}$ De Virginitate XIX.2 purpureos pudicitiae flores ex sacorum voluminum prato decerpens

${ }^{20}$ Ehwald, ed. Opera, 487-494, 327-471 respectively.

${ }^{21}$ Lapidge and Herren, eds. Prose Works, 15.
} 
saints, his reformulation of patristic views of marriage and female sexuality, and his seemingly converse note of censuring the ostentatious dress of women. These unusual aspects have led some to argue that Aldhelm either had no "clearly designed principal"22 or that he merely equivocated in his approach. ${ }^{23}$ I would suggest that these readings can be improved and that it is possible to reconcile the conflicting aspects of Aldhelm's prose. The best way to reconcile the disparate elements of this work may be to understand the De Virginitate as an organized attempt to defend the double monastery from its critics.

Supporting this proposition requires an understanding of the various social tensions that surrounded the double monastery in seventh-century England. It seems clear that Anglo-Saxon society was far from insular in nature and had significant ties to the continent. The argument that much of northern Europe had essentially similar cultural traits, often with overlapping political ties, ${ }^{24}$ has repeatedly been made over the last twenty years. ${ }^{25}$ Rosamond McKitterick has argued for a high degree of cultural unity between the continent and the British Isles based upon manuscript evidence. She argues that the evidence shows a "wide network of communication and the preservation of religious and intellectual links from the seventh century well into the Carolingian period

\footnotetext{
${ }^{22}$ Lapidge and Herren, eds. Prose Works, 58.

${ }^{23}$ Hollis, Anglo-Saxon Women and the Church, 84.

${ }^{24}$ e.g. Ian Wood, The Merovingian North Sea, Occasional Papers on Medieval Topics; 1 (Alingsås, Sweden: Viktoria Bokförlag, 1983). ibid. The Merovingian Kingdoms, 450-75I (London and New York: Longman, 1994), 176-183.

${ }^{25}$ e.g. James Campbell, "The First Century of Christianity in England," in Essays in Anglo-Saxon History (London ; Ronceverte, W. Va.: Hambledon Press, 1986), 49-67. David Ganz, "Corbie and Neustrian Monastic Culture 661-849," in La Neustrie: Les pays au nord de la Loire de 650-850, ed. Hartmut Atsma (Paris: Jan Thorbecke Verlag Sigmaringen, 1989), 340-343. Henry Mayr-Harting, The Coming of Christianity to England (New York, Schocken Books, 1972), 103-113. Rosamond McKitterick, "The Diffusion of Insular Culture in Neustria between 650 and 850: The Implications of the Manuscript Evidence," in La Neustrie: Les Pays au Nord de la Loire de 650-850, ed. Hartmut Atsma (Paris: Jan Thorbecke Verlag Sigmaringen, 1989), 430.
} 
and beyond." This leads to her conclusion that the "Channel does not represent a great divide. Franks and English had much in common" ${ }^{26}$ Similarly, Ian Wood has made the argument for Merovingian political hegemony of at least part of Britain in the sixth and seventh centuries. ${ }^{27}$ While this project has its main focus on individuals and institutions located in Britain, the essential continuity with continental affairs should not be overlooked.

The late seventh century witnessed a remarkable confluence of Roman, Greek, and Celtic religious and cultural traditions in Anglo-Saxon England. ${ }^{28}$ The resulting religious conflicts are most famously evidenced by Bede with his dramatic description of the debate between the supporters of Irish and Roman religious practice at the Synod of Whitby in $664 .^{29}$ Bede's description of the conflict along national lines seems to be decidedly influenced by his desire to contrast the orthodoxy of those following the Roman tradition with the heterodoxy of the Irish. However, interpretations that follow Bede's narrative too closely overemphasize the binary nature of the conflict by not allowing for his bias for things Roman ${ }^{30}$ and the degree to which the debate was in many ways Irish versus Irish. ${ }^{31}$ The conflict that did take place was not split along national origins, but was a result of the varied response to the influx of new religious traditions.

\footnotetext{
${ }^{26}$ McKitterick, "The Diffusion of Insular Culture in Neustria between 650 and 850: The Implications of the Manuscript Evidence," 430. c.f. Campbell's comment in reference to Augustine's mission the "Channel was not necessarily the most important of boundaries he crossed; so far as religion and culture went the crucial divide was further south." Campbell, "The First Century of Christianity in England." 54.

${ }^{27}$ Wood, The Merovingian Kingdoms, 450-751, 176-83.

${ }^{28}$ The use of these broad terms is not meant to imply that they are best understood as hermetically sealed categories nor do they properly represent the immense variation that is present within each. Despite the potential for misunderstanding that the use of these terms creates, their utilization is unavoidable to the extent that connection to the historiographical tradition necessitates it.

${ }^{29} H E$ III. 25

${ }^{30}$ see below pp 36-7.

${ }^{31}$ Mayr-Harting, The Coming of Christianity to England, 106.
} 
Bede's narrative is one example of how Anglo-Saxons might have approached the introduction of Mediterranean religious customs.

However, his response was not the only one that was possible. I would suggest that Aldhelm represents an informative case study for the ways in which individuals negotiated their identities between conflicting traditions. These traditions should not be defined so much along national or even theological lines, but rather upon the application of theological principles in social practice. ${ }^{32}$ Aldhelm's experience makes the study of his work most compelling. First, while he was educated in Ireland, he later denounced these roots after studying at Theodore and Hadrian's school. ${ }^{33}$ His letter to Heathfrith, a scholar just returning from study in Ireland, complains that there is no need for students to travel to Ireland any longer as Theodore's school is clearly superior. ${ }^{34}$ Secondly, Aldhelm was a high-ranking member of the local nobility and was eventually promoted to an abbacy and later an episcopal see. ${ }^{35}$ This would have placed him in the conflicted position as an Anglo-Saxon nobleman and as a member of the 'Roman' ecclesiastical hierarchy. Therefore my interpretation of the De Virginitate reads it as Aldhelm's attempts to reconcile these distinct traditions into a synthesis viable for his own place and time.

Historiographical Issues

Previous scholarship has generally been unable to understand the De Virginitate

${ }^{32}$ Campbell, "The First Century of Christianity in England," 64.

${ }^{33}$ Ehwald, ed. Opera, 475-80. Lapidge and Herren, eds. Prose Works, 152-55.

${ }^{34}$ Ehwald, ed. Opera, 492-493.

${ }^{35} H E$ V. 18 
in such a context for a number of reasons. Perhaps the most significant of these is the dominance of a historiographical tradition that has limited an understanding of the possibilities in seventh-century England. The study of mixed-sex monastic communities in early medieval Europe has long proven to be problematic for historical interpretation. While the topic was actively debated in the nineteenth century, it has only recently returned to prominence in medieval studies through the lens of feminist discourse. ${ }^{36}$ The discussion of double monasteries in the nineteenth century was heavily influenced by nationalistic concerns with the primary topic of inquiry being the Irish or Celtic influence upon the propagation of the institution..$^{37}$ While this nationalist line of inquiry ensured continued interest in double monasteries through the beginning of the twentieth century, the topic was generally neglected until it was addressed by feminist scholars. These scholars' interest in the institution has been based upon the fact that double monasteries seemed to represent a place where women were able to exercise significant social, economic and political power. The ability of women to hold power in Northern Europe and Anglo-Saxon England in particular, was celebrated as a time that showed what "women can accomplish if the age affords them the opportunity." 38

This theory of a pre-modern 'golden age' for women has been advanced on both legal and economic fronts. Alice Clark first introduced the argument for a medieval

\footnotetext{
${ }^{36}$ c.f. Bateson, "The Origin and Early History of Double Monasteries." Thompson, "The Ministry of Women." While the earlier focus upon double monasteries was prompted in many ways by nationalistic religious controversies, the modern emphasis has arisen out of feminist scholarship concerned with the powerful roles occupied by the abbesses. e.g. For an example from the nineteenth c. see Varin, "Memoire." Modern examples include Christine E. Fell, Women in Anglo-Saxon England (London: British Museum Publications, 1984). Peyroux, "Abbess and Cloister: Double Monasteries in the Early Medieval West." Wemple, Women in Frankish Society: Marriage and the Cloister, 500 to 900.

${ }^{37}$ Peyroux, "Abbess and Cloister: Double Monasteries in the Early Medieval West," 2-34.

${ }^{38}$ Wemple, "Sanctity and Power: The Dual Pursuit of Early Medieval Women," in Becoming Visible: Women in European History, ed. Claudia Koonz, Renate Bridenthal, and Susan Stuard (Boston: Houghton Mifflin Company, 1987), 131.
} 
economic 'golden age' for women in 1919 when she favorably compared the economic position of medieval women to that of their modern counterparts. ${ }^{39}$ She argued that the rise of capitalism adversely affected the ability of women to maintain economic status. This view that pre-modern and pre-industrial women were relatively better off has also been put forth most recently by Louise Tilly and Joan Scott. ${ }^{40}$

The legal position of women in Anglo-Saxon England has also been argued to be a relatively egalitarian system. Frank Stenton has argued that Anglo-Saxon women controlled large amounts of property based upon an analysis of place names. ${ }^{41}$ Similarly, Doris Stenton held that that "in Anglo-Saxon England men and women lived on terms of rough equality with each other" with regards to their legal standing and property rights. ${ }^{42}$ More recently, authors such as Sheila Dietrich, Christine Fell and Suzanne Wemple have also affirmed this conceptualization. ${ }^{43}$ However, any emplotment of history that includes a 'golden age' must also, by its very nature, include an inevitable fall from grace. For Anglo-Saxon gender relations this point is often understood to be the period following the Norman Conquest of $1066 .^{44}$

\footnotetext{
${ }^{39}$ Alice Clark, Working Life of Women in the Seventeenth Century, Reprints of Economic Classics (New York: A.M Kelley, 1968).

${ }^{40}$ Louise Tilly and Joan Scott, Women, Work, and Family (New York: Methuen, 1987).

${ }^{41}$ Frank Stenton, "The Historical Bearing of Place-Name Studies: The Place of Women in Anglo-Saxon Society," Transactions of the Royal Historical Society 25, no. 1 (1943), 1-13.

${ }^{42}$ Doris Mary Stenton, The English Woman in History (London: George, Allen and Unwin Ltd, 1957), 28.

${ }^{43}$ Sheila Deitrich, "An Introduction to Women in Anglo-Saxon Society (C. 600-1066)," in The Women of England from Anglo-Saxon Times to the Present, ed. Barbara Kanner (Hamden, Conn.: Archon, 1979), 3256. Fell, Women in Anglo-Saxon England. Fell, "Some Implications of the Boniface Correspondence," in New Readings on Women in Old English Literature, ed. Helen Damico and Alexandra Hennessey Olsen (Bloomington: Indiana University Press, 1990), 29-43. Wemple, Women in Frankish Society: Marriage and the Cloister, 500 to 900. Ibid. "Sanctity and Power: The Dual Pursuit of Early Medieval Women." In Becoming Visible: Women in European History, ed. Claudia Koonz, Renate Bridenthal, and Susan Stuard, (Boston: Houghton Mifflin Company, 1987), 131-151.

${ }^{44}$ esp. Fell, Women in Anglo-Saxon England; Stenton, The English Woman in History.
} 
The idea of a 'golden age' for women that then diminished, either with industrialization or with the Norman Conquest has been repeatedly challenged over the last two decades. The majority of the objections are regarding the location of a particular date or event upon which to pin the decline of women's status. Catherine Cubitt and Pauline Stafford, among others, have questioned the efficacy of describing the Norman Conquest as the turning point in gender relations by showing significant aspects of continuity in gender ideology before and after $1066 .^{45}$ Similarly, Barbara Hanawalt wrote that "the quest for an E1 Dorado in women's economic history is misleading." These sensible refinements to the comparative legal and economic position of women at different points are well taken and can further our understanding of the period. However, if the idea of a 'golden age' is overwrought, excessive criticism of such an idea can lead to even worse excesses.

Perhaps the most virulent criticism of the idea of a 'golden age' has come from Judith Bennett. Bennett has argued in successive publications not only that there has been no 'golden age' for women, but that there has been no change at all in the low status of women. ${ }^{47}$ While in her earliest work she explicitly denied any real change had ever occurred in the lives of women, she has since modified that view under pressure to make a distinction between "changes in women's experiences on the one hand and

\footnotetext{
${ }^{45}$ Catherine Cubitt, "Virginity and Misogyny in Tenth and Eleventh Century England," Gender and History 12, no. 1 (2000), 18-38. Hollis, Anglo-Saxon Women and the Church. Anne Klinck, "Anglo-Saxon Women and the Law," Journal of Medieval History 8 (1982), 107-121. Pauline Stafford, "Women and the Norman Conquest," Transactions of the Royal Historical Society 6, no. 4 (1994), 221-249.

${ }^{46}$ Barbara Hanawalt, ed. Women and Work in Preindustrial Europe (Bloomington: Indiana University Press, 1986), xiv.

${ }^{47}$ Judith Bennett, "History that Stands Still: Women's Work in the European Past," Feminist Studies 14, no. 2 (1988), 269-283. "Feminism and History," Gender and History 1, no. 3 (1989), 251-272. "Confronting Continuity," Journal of Women's History 9, no. 3 (1997), 73-94.
} 
transformation in women's status on the other." ${ }^{\text {48 }}$ Thus, while the economic position of women might get better or worse over any particular time period, the status of women is never actually transformed beyond subjugation to men. Bennett will admit that change does take place, but the progress has been so slow as to be irrelevant. She explains that transformations are still being written in women's history, not because they are there, but rather because "our profession expects it from us, our feminist politics seems to need it, and our own lived experiences seem to support it." ${ }^{, 49}$

The positioning of patriarchy as central to all discussion of the past is problematic for historical inquiry. It tends to reduce history to monocausal descriptions that provide "endless variations on the unchanging theme of a fixed gender inequality." enshrining the binary opposition of male and female, this type of analysis ultimately is based upon an ahistorical biological essentialism. Worse still, a historical inquiry beginning with the assumption that gender relations are inherently conflicted will be unable to recognize potential interaction between male and female in the past. ${ }^{51} \mathrm{~A}$ process of constructing the past that essentializes gender conflict is incapable of recognizing the possibility of egalitarian gender relations.

Yet scholars are certainly right to caution against an idealistic quest for a 'golden age' for women. There is no unproblematic period in the past. Modern society has not fallen from an ungendered Eden. Walter Goffart has admirably summed up its rhetorical purpose: "What is a retrospective golden age if not a stick with which to beat the

\footnotetext{
${ }^{48}$ Bennett, "Confronting Continuity," 73.

${ }^{49}$ Bennett, "Confronting Continuity," 82.

${ }^{50}$ Joan Scott, "Gender: A Useful Category of Historical Analysis," The American Historical Review 91, no. 5 (1986), 1053-1075: 1057.

${ }^{51}$ Judith Butler, Gender Trouble: Feminism and the Subversion of Identity (New York: 1990).
} 
present?"52 But to argue that a system of eternal patriarchy is the only way in which we can understand the past, and by extension, the only reality that those in the past could have lived, is to deny the rich and varied nature of our evidence and the experiences of individuals in the past. Yet, perhaps the greater problem for understanding medieval conceptions of gender lies in the way that many historians have attempted to place their studies within these extremely broad rubrics. Even a cursory examination of the evidence reveals the very specific ways that gender was understood at various times and locations. While comparative approaches can provide valuable insights, the basis of our understanding of gender relations must remain fixed to a specific time and place.

The 'Male Element' in the Double Monasteries

It is within this context that the understanding of the nature and practice of the double monastery has itself developed. The most problematic issue for historians attempting to interpret the double monastery is how to reconcile its 'doubleness.' There has recently been a movement towards jettisoning the term double monastery altogether as it is considered anachronistic and all-inclusive. ${ }^{53}$ The charge of anachronism stems from the fact that the term monasterium duplex was not used by contemporaries to

\footnotetext{
${ }^{52}$ Walter Goffart, The Narrators of Barbarian History (A.D. 550-800): Jordanes, Gregory of Tours, Bede, and Paul the Deacon (Princeton: Princeton University Press, 1988), 254.

${ }^{53}$ e.g. Sharon K. Elkins, Holy Women of Twelfth-Century England, Studies in Religion (Chapel Hill; London (England): University of North Carolina Press, 1988). Penelope Johnson, Equal in Monastic Profession: Religious Women in Medieval France (Chicago: University of Chicago Press, 1991). Penny Schine Gold, "Male/Female Cooperation: The Example of Fontevrault," in Medieval Religious Women, ed. John and Shank Nichols, M. Thomas, Cistercian Studies Series; No. 71 (Kalamazoo, MI: Cistercian Publications, 1984), 151-168. See also a summary of the case for and against dismissing the term double monastery in Peyroux, "Abbess and Cloister: Double Monasteries in the Early Medieval West," 4447.
} 
describe the institution. While this may be so, there is substantial evidence that contemporaries did distinguish mixed sex from single sex foundations. ${ }^{54}$ As for the charge of vagueness, Penelope Johnson has argued that “in reality all women's houses were 'double' insofar as they all had priests attached to them for administering the sacraments and were headed by abbesses or prioresses." ${ }^{, 55}$ Certainly these objections are useful in that we must be conscious of varied relations between monastic men and women. Yet, the argument that we cannot make a useful distinction between a nunnery with a single priest and communities of monks and nuns does not seem helpful for understanding. We should also take care to maintain the emphasis upon the tension in the gendered relationship that the term 'double' forces us to take into account. ${ }^{56}$

Another point regarding the definition of the double monastery is a tendency to minimize the dual sex nature of the institution by understanding the male element as limited to providing labor and administering the sacraments to the nuns. Henry MayrHarting described the double monastery as a place where

"high-born women founded nunneries on their own estates and communities of men became associated with them in order to offer mass, give the sacraments, and to assist in the administrative and manual tasks which it was difficult for the women to perform alone., 57

Similar definitions have also been offered by a number of other scholars. Clifford Lawrence described the "Columbanian" ${ }^{\text {,5 }}$ double monasteries of Gaul as "essentially communities of nuns, to which communities of monks were attached in order to provide

\footnotetext{
${ }^{54}$ Peyroux, "Abbess and Cloister: Double Monasteries in the Early Medieval West," 46.

${ }^{55}$ Johnson, Equal in Monastic Profession: Religious Women in Medieval France, 7.

${ }^{56}$ Peyroux, "Abbess and Cloister: Double Monasteries in the Early Medieval West," 47.

${ }^{57}$ Mayr-Harting, The Coming of Christianity to England, 151.

${ }^{58}$ For an evaluation of the Celtic origins of double monasteries see Peyroux, "Abbess and Cloister: Double Monasteries in the Early Medieval West," 4-18.
} 
priests and heavier manual services." 59 The assessment that men were only present in double monasteries for manual labor and the administering of sacraments has a certain practical appeal. ${ }^{60}$ It handles the 'doubleness' quite neatly as it removes the problem of having to reconcile the apparent supervision of religious women over religious men. If the men were really just manual laborers or the 'male element' simply consisted of a single priest then there would be no difficulty in imagining medieval society placing religious women in these positions of authority.

Yet, upon closer scrutiny, this explanation does not seem to contain much interpretive value. First of all, it seems clear that while a priest might be necessary to administer the sacraments, a female community would only need a single individual to accomplish the task. Secondly, if it is reasonable to believe that there was a certain division of labor at the double monasteries there is evidence of women performing their own heavy lifting and quasi-sacerdotal activities. ${ }^{61}$ We also have clear evidence of at least one case where men were in residence for scholarly training. Bede mentions that five bishops were trained under Hild at Whitby. ${ }^{62}$ It is hard to imagine that these men were there "to assist in the administrative and manual tasks which it was difficult for the women to perform alone." ${ }^{, 63}$ Furthermore, it is clear that men desired to be included under

\footnotetext{
${ }^{59}$ Clifford Hugh Lawrence, Medieval Monasticism: Forms of Religious Life in Western Europe in the Middle Ages, 2 ed. (London: Longman, 1989), 52.

${ }^{60}$ The argument that men were only in the double monasteries for labor and the administering of the sacraments has become so commonplace it seems as if scholars no longer feel it needs to be proved or cited. As far as I have been able to ascertain this argument can be traced back to Thompson, "The Ministry of Women."

${ }^{61}$ Wemple, Women in Frankish Society: Marriage and the Cloister, 500 to 900, 160.

${ }^{62} \mathrm{HE}$ IV 23.5.1

${ }^{63}$ Mayr-Harting, The Coming of Christianity to England, 151.
} 
the protection and guidance of powerful abbesses. ${ }^{64}$ Should the fact that double monasteries served as educational centers and stepping-stones to higher office for men come as any surprise? Given what we know about the highly developed literary culture in these institutions it would seem to be a natural place to obtain an exemplary education. ${ }^{65}$ Abbesses were high-ranking members of the nobility and participated fully in the systems of patronage and protection that were prevalent in Anglo-Saxon England. ${ }^{66}$

To view the men in double monasteries as essentially ancillary and only providing service to the noble women does a disservice to both parties. While it is reasonable to conclude that men may have participated in the heavy labor required to run a monastery, ${ }^{67}$ it can by no means explain away the mixing of the sexes at double monasteries. Neither is it realistic to attempt to explain away the men in these institutions as only necessary for sacerdotal functions. What is interesting here is that there apparently is a need to account for the presence of men in this manner. The implicit assumption in these efforts to 'disappear' the male element in double monasteries would seem to be that the early Middle Ages could not have condoned the fact that a woman could rule over a man of the same class, especially in a monastic environment. The necessity of understanding the male element in the double monasteries as laborers is derived from the concurrent need to delegitimate the apparent authority of the abbess. Similarly, the explanation of men's presence being solely needed for the purpose of

\footnotetext{
${ }^{64}$ Michael Tangl, ed. Die Briefe des Heiligen Bonifatius und Lullus, Monumenta Germaniae Historica: Epistolae Selectae, vol. 1 (Munich: Weidmann, 1989), 78-80.

${ }_{65}$ e.g. Rosamond McKitterick, The Carolingians and the Written Word (Cambridge: Cambridge University Press, 1989), 223-227. Felice Lifshitz, "Demonstrating Gun(T)za:Women, Manuscripts, and the Question of Historical Proof," in Vom Nutzen des Schreibens, ed. Walter Pohl and Helmut Reinitz (Vienna: forthcoming).

${ }^{66}$ Fell, "Some Implications of the Boniface Correspondence," 32-33.

${ }^{67}$ Joan Nicholson, "Feminae Gloriosae: Women in the Age of Bede," in Medieval Women, ed. Derek Baker (Oxford: Blackwell, 1970), 19.
} 
sacerdotal functions both limits the number of men present and emphasizes the spiritual superiority of men through the office of priesthood.

In order to understand any part of Anglo-Saxon gender relations we must focus on specific and discernable elements that can be placed within a historical context. Felice Lifshitz has recently argued that we should "begin to develop a series of regionally- and temporally-differentiated pictures of gender conceptualizations." ${ }^{.68}$ If we are to speak about Anglo-Saxon gender relations it must be with an essential specificity of time and place. This is the approach that is needed for understanding Aldhelm of Malmsbury's De Virginitate.

The first section of this work will be devoted towards establishing the operative factors that helped shape Aldhelm's conceptions of gender and his understanding of the double monastery. Here I will attempt to establish the purpose and function of the De Virginitate and examine the various factors that may have prompted its composition and influenced its content. Because of the dynamic and international nature of Anglo-Saxon society in the seventh century, this task will necessitate discussion of evidence from both the well-known Boniface correspondence and, less obviously, eastern Mediterranean religious culture. An understanding of the various social, political and cultural elements that were in conflict in seventh-century Anglo-Saxon England will then allow for an informed reading of the De Virginitate.

The second section of this work will argue that the De Virginitate represents a theological justification both for the double monastery as an institution and for its

\footnotetext{
${ }^{68}$ Lifshitz, "Gender and the Exemplarity East of the Middle Rhine: Jesus, Mary and the Saints in Manuscript Context," 4.
} 
depiction of an egalitarian imaginary in Anglo-Saxon England of the seventh century. By analyzing Aldhelm's adaptation of orthodox sources, I will then attempt to show how he utilized these sources to fit the needs of the double monastery.

Evidence from Anglo-Saxon society, and the double monastery in particular, appears to offer the possibility that a relatively egalitarian conception of gender relations did exist at this time. Yet, until recently there has been little evidence to show that such a belief was anything more than "the survival of indigenous custom." has recently argued that the high position of women in post-conversion Anglo-Saxon England was only the result of this cultural holdover and that the 'church' guided by the misogyny inherited from patristic sources proceeded to erode the position of women. ${ }^{70}$ This view can only be supported if we imagine those who received this patristic tradition did so blindly and that the tradition was uniformly misogynistic to begin with. Yet, without a theological justification of egalitarian gender relations from a respected member of the orthodoxy, it can be difficult for modern historians to imagine anything else. There are certainly hints that such a mental framework did indeed exist. Fortunately, the scholarship on this point is beginning to develop. Individual studies have argued that gender may not have been the most significant aspect of relationships between men and women in Anglo-Saxon society. ${ }^{71}$ it is a mistake to read selected examples of misogynistic patristic texts into the medieval time period without regard to

\footnotetext{
${ }^{69}$ Hollis, Anglo-Saxon Women and the Church, 2.

${ }^{70}$ Hollis, Anglo-Saxon Women and the Church, 2-3.

${ }^{71}$ e.g. Jo Ann McNamara, Sisters in Arms: Catholic Nuns through Two Millennia (Cambridge: Harvard University Press, 1996). Nicholson, "Feminae Gloriosae; Women in the Age of Bede." Alain Renoir, "Eve's I.Q. Rating: Two Sexist Views of Genesis B," in New Readings on Women in Old English Literature, ed. Helen Damico and Alexandra Hennessey Olsen (Bloomington; Indiana University Press, 1990), 262-272.
} 
evidence of either their presence or acceptance in a particular historical context. We are beginning to accumulate enough evidence to be able to move the discussion away from seeing cooperative relationships as exceptions, towards understanding them as pieces of a larger pattern. I would argue that Aldhelm's De Virginitate can provide another such example.

Aldhelm of Malmesbury was one of the leading intellectuals of his time. He lived in a complex world where his own identity needed to be balanced between conflicting loyalties and traditions. Similarly, the double monastery was an institution that was situated in an environment that was often hostile to the basic tenets of its existence. The double monastery has most often been understood as, at best, an aberration in the overwhelming misogynistic culture of Early Medieval Europe and, as a result it has been alternately dismissed, minimized or ignored. This project will contribute to a balancing of that assessment by showing that the De Virginitate is an example of a defense of the double monastery. 


\section{Chapter 2}

The De Virginitate was widely read and studied throughout northern Europe in the early Middle Ages. ${ }^{72}$ Modern historians often present Aldhelm's work as having a rambling and cumbersome style. ${ }^{73}$ Yet it also seems clear that while his Latin may be quite challenging, the audience apparently had sufficient capabilities to understand it. In fact, the degree to which Aldhelm's influence can be seen in the Boniface Correspondence would seem to indicate that his style was not only comprehensible, but it was, for better or worse, replicated as well. ${ }^{74}$ Aldhelm's stylistic influence was both widespread and long lasting. Andy Orchard has argued that "practically every AngloLatin hexameter composition penned within a century of his death is heavy with his influence., ${ }^{, 75}$ However, I would suggest that amidst this concern, significant aspects of the content of De Virginitate have sometimes been overlooked.

A brief description of the structure and contents of the De Virginitate is necessary to begin. The treatise can be divided into three parts. Aldhelm begins with a theological discourse on the nature of virginity. ${ }^{76}$ The core of this section is Aldhelm's tripartite division of female spirituality along the lines of virginity, chastity, and marriage. ${ }^{77}$ In the center of the De Virginitate is a collection of male and female saints who exemplify the values put forth in the first section. Aldhelm gives brief sketches of fifty-seven saints in

\footnotetext{
${ }^{72}$ Fell, Women in Anglo-Saxon England, 109. Hollis, Anglo-Saxon Women and the Church, 78.

${ }^{73}$ Hollis, Anglo-Saxon Women and the Church, 78. Lapidge and Herren, eds. Prose Works, 58.

${ }^{74}$ Tangl, ed. Die Briefe des Heiligen Bonffatius und Lullus.

${ }^{75}$ Orchard, The Poetic Art of Aldhelm, 239.

${ }^{76}$ De Virginitate I-XIX

${ }^{77}$ De Virginitate XIX
} 
order to exemplify the virtues that he set forth in the first section. ${ }^{78}$ These descriptions are laid out in more or less chronological order beginning with the Old Testament and moving forward to New Testament figures, martyrs and later saints. They are also divided according to sex, with the male saints coming first followed by the female saints. One curious break in this pattern is Aldhelm's inclusion of the lives of Joseph, David, Samson, Abel and Melchisedech at the end of the section of the female saints. Finally, Aldhelm ends his work with a condemnation of extravagant clothing. ${ }^{79}$ Relying heavily upon Cyprian's De Habitu Virginum, Aldhelm warns against the danger of pride and ostentatious dress.

The intended purpose of the De Virginitate has been a matter of some dispute. Aldhelm states in the De Virginitate that "while proceeding to an episcopal convention" ${ }^{80}$ he had received letters from the women at Barking and that it was these letters that elicited his work. ${ }^{81}$ Michael Lapidge has argued that Aldhelm's purpose in responding to the nuns at Barking was "a didactic one: from his own vast reading in hagiography and patristic literature he was attempting to compile an anthology of saintly models for the Barking ladies to peruse at leisure. ${ }^{, 82}$ In essence, he says that Aldhelm used the requests of the nuns at Barking to write a long and flowery treatise on virginity, that while interesting to the learned nuns, was intended more to showcase Aldhelm's literary ability than for any particular problem. This is certainly not an unreasonable argument; the $D e$

\footnotetext{
${ }^{78}$ The Carmen De Virginitate omits five of the saints included in the prose version, but includes three others. De Virginitate XX-LIII

${ }^{79}$ The Carmen replaces this section with one describing an allegorical conflict between the virtues and vices. De Virginitate LIV-LX

${ }^{80}$ De Virginitate 1.1 ad pontificale proficiscens conciliabulum

${ }^{81}$ De Virginitate LX.2 iteratis totidem epistolarum scriptis instigare dignemini, quod praecedentem libelli textum

${ }^{82}$ Lapidge and Herren, eds. Prose Works, 58.
} 
Virginitate follows in a long tradition of patristic literature concerning virgins and Aldhelm was certainly cognizant of his place in that tradition. Similarly themed works were written by Tertullian, Cyprian, Jerome, Ambrose and Augustine and it is clear that Aldhelm was familiar with them as he repeatedly refers to them in his own work and it likely that he wished to follow in their tradition.

On the other hand, Henry Mayr-Harting has argued that Aldhelm's true purpose for writing the De Virginitate was the "admonition against pride in these high-born nuns, particularly pride in the kind of clothes they wore." 83 Again, the evidence for his approach is not insubstantial. Aldhelm spends a large portion of the final third of his work quoting from Cyprian's De Habitu Virginum and its condemnation of women's dress in a standard diatribe upon women. ${ }^{84}$ Yet ultimately, neither Lapidge's nor MayrHarting's arguments are wholly convincing. It is my contention that this work was specifically tailored to the needs and concerns of the double monastery and can also be read as a practical defense of the double monastery, rather than simply a literary exercise.

There are several obstacles to understanding Aldhelm's work. One of the greatest impediments is the previously mentioned difficulty of Aldhelm's Latin. ${ }^{85}$ Perhaps it is for this very reason that most treatments of Aldhelm's work have focused more upon his style than the content. Lapidge went so far as to suggest that while a certain degree of logic can be teased out of the first nineteen chapters, "it may be futile to seek a clearly designed principal" in the De Virginitate." ${ }^{86}$ However, the interpretation I propose shows

\footnotetext{
${ }^{83}$ Mayr-Harting, The Coming of Christianity to England, 194.

${ }^{84}$ c.f. $H E$ IV. 25

${ }^{85}$ Hollis, Anglo-Saxon Women and the Church, 78. Lapidge and Herren, eds. Prose Works, 58. MayrHarting, The Coming of Christianity to England, 193.

${ }^{86}$ Lapidge and Herren, eds. Prose Works, 58.
} 
the work to be tightly focused in content and presentation. If Aldhelm did not always chose the most economical style to present his work, he had a reason for what he did.

\section{Structure and Function of the Double Monastery}

Aldhelm specifically addresses several members of the monastery and demonstrates knowledge and appreciation for their scholarship in the opening passages of the De Virginitate. ${ }^{87}$ Of the ten women he names in the introduction, at least two are verifiably of high noble origin and Aldhelm claims one as a relative. One example of the women whom Aldhelm mentions is Cuthburg who has been identified as the sister of King Inne of Wessex and the divorced wife of King Aldfrith of Northumbria. ${ }^{88}$

The noble backgrounds of the female members of Barking most likely influenced the deference and respect that Aldhelm gave the community throughout the course of his work. ${ }^{89}$ His personal knowledge of the members of Barking and his statements that the De Virginitate was a direct response to their requests indicate that he was not merely using this opportunity to compile a treatise on virginity. Instead it would seem more likely that it is a direct response to issues raised by the nuns.

The double monastery should not be considered exceptional in these contexts, as it was often the preferred type of monastery in areas of France, England, the Rhineland, and Spain during the sixth through the eighth centuries, albeit for different reasons and in

\footnotetext{
${ }^{87}$ De Virginitate II

${ }^{88}$ Lapidge and Herren, eds. 52 and Ehwald, ed. Opera, 229, note 1.

${ }^{89}$ e.g. While the flattery of the opening lines might be expected, the favorable references to the women's scholarship and spirituality would seem to indicate genuine respect. See also Fell, Women in Anglo-Saxon England, 111 .
} 
different contexts. ${ }^{90}$ For instance, Anglo-Saxon double monasteries have been imagined as the administrative centers for pastoral care. Indeed, it has been argued that this was their primary function. ${ }^{91}$ While this theory is supported by a good deal of evidence, it is unclear whether the nuns themselves were active in these types of roles or if this was a function of male preachers attached to the minster. ${ }^{92}$ However, it is reasonable to believe that these women, who often had a great deal of power and influence before joining the double monastery, continued to exercise influence in the ecclesiastical hierarchy. It is important when thinking about the double monastery to consider both its role in the society and the institutional authority the position provided the abbess.

Before we proceed to a discussion of the temporal attributes of the double monastery we must first understand its 'doubleness.' If we are to understand the institution of the double monastery we must at least attempt to speak to the ways in which ecclesiastical men and women associated with one another at this time. The specific evidence for the living arrangements in double monasteries are rather sparse but it seems clear that actual practice varied a great deal. ${ }^{93}$ However, it seems that extreme

\footnotetext{
${ }^{90}$ Campbell, "The First Century of Christianity in England," 61. Peyroux, "Abbess and Cloister: Double Monasteries in the Early Medieval West."

${ }^{91}$ John Blair, "Anglo-Saxon Minsters" Pastoral Care Before the Parish ed. John Blair and Richard Sharpe (Leicester: Leicester University Press, 1992), 226-266; Blair, Minsters and Parish Churches: The Local Church in Transition, 950-1200. (Oxford: Oxford University Committee for Archaeology, 1988); John Godfrey, "The Place of the Double Monastery in the Anglo-Saxon Minster System" in Famulus Christi: Essays in Commemoration of the Thirteenth Centenary of the Birth of the Venerable Bede ed. by Gerald Bonner (London: SPCK, 1976), 346; Alan Thacker, 'Monks, Preaching and Pastoral Care in Early AngloSaxon England" Pastoral Care Before the Parish ed. John Blair and Richard Sharpe (Leicester: Leicester University Press, 1992), 137-70.

${ }_{92}$ Godfrey, 348. Also see Wemple, Women in Frankish Society: Marriage and the Cloister, 500 to 900 , 129-43 for women's roles in the diaconate and pastoral care.

${ }^{93}$ Archaeological evidence that is site specific to Barking would help to unravel the actual living arrangements of the women to whom Aldhelm is writing but unfortunately none is available. The site was excavated in 1910 by Alfred Clapham but there was apparently little or no evidence that survived from the Anglo-Saxon period. See Clapham. "The Benedictine Abbey of Barking: A Sketch of its Architectural
} 
segregation of men and women was not the norm. As Joan Nicholson put it: "It was no use entering a monastery to get away from men and doubtful whether anyone really wanted to.. ${ }^{.94}$ Yet the close contact of men and women in a monastic setting was a concern for some and occasioned charges of scandal.

The most infamous example of scandal at a double monastery comes from Bede's condemnation of Coldingham where he blames the destruction of the double monastery by fire upon the wickedness of its members. ${ }^{95}$ This example is occasionally cited as showing the illegitimacy of close contact between monastic men and women. ${ }^{96}$ Yet it seems that what worried Bede about Coldingham was not the physical danger of "casual association between its male and female members, ${ }^{, 97}$ but rather the spiritual offense of neglecting their duties for feasting and slothful slumber. ${ }^{98}$ This is further emphasized by the contrast Bede draws between the dutiful Adamnan and the neglectful monks and nuns. ${ }^{99}$ Adamnan is not praised for his virginity and purity as we might expect if the passage was about to condemn the association of male and female. Rather, he is praised for keeping his vigils and his earnest prayers. Similarly, Bede does not inform us of sexual transgressions between the monks and nuns. Instead the "men and women alike" are castigated for their "feasting, drinking, gossip." This passage may be evidence that

History and an Account of Recent Excavations on its Site" Transactions of the Essex Archaeological Society, 12 (1913), 69-89.

${ }_{94}$ Nicholson, "Feminae Gloriosae: Women in the Age of Bede," 19.

${ }^{95} H E$ IV. 25

${ }^{96}$ McNamara, Sisters in Arms: Catholic Nuns through Two Millennia, 145.

${ }^{97}$ McNamara, Sisters in Arms: Catholic Nuns through Two Millennia, 145.

${ }^{98}$ This passage might best be understood as fitting into his greater didactic purpose of denigrating 'lesser' monastic foundations and his desire to see the lands of such institutions be transferred for the endowment of additional bishoprics. D.P. Kirby, "Bede's Historia Ecclesiastica Gentis Anglonum: Its Contemporary Setting," in Bede and His World (Aldershot: Variorum, 1992), 903-926.

${ }^{99}$ HE IV.25.4 
there was some contact between monks and nuns at Coldingham, but not that the problems there were of a sexual nature. ${ }^{100}$

When we imagine the monasteries of seventh-century England we should not envision them as an enclosed and isolated institution. To do so is to impose the strictures of later developments in monastic practice back onto the early Middle Ages. The monasteries of this period do not fit neatly into dyadic structures of lay/clerical, male/female, or active/passive, if monasteries indeed ever did. Any attempt to restrict these individuals and institutions to such categories cannot help but lead to misunderstandings.

The political and social importance of the mixed sex foundations was quite considerable ${ }^{101}$ and its management was no small task. The point that the double monastery served as the center for ecclesiastical administration deserves particular emphasis. ${ }^{102}$ There has been an ongoing debate regarding the nature of pastoral care in the Anglo-Saxon church and whether it was centered upon episcopal or monastic institutions. ${ }^{103}$ John Blair has argued that the minster, in addition to the more familiar

\footnotetext{
${ }^{100}$ See also Hollis, Anglo-Saxon Women and the Church, 245.

${ }^{101}$ See below, pp 28-29

102 John Blair, "St Frideswide Reconsidered," Oxoniensia 52 (1987), 71-127: 87-88. Foot, "The Role of the Minster in Earlier Anglo-Saxon Society," in Monasteries and Society in Medieval Britain: Proceedings of the 1994 Harlaxton Symposium, ed. Benjamin Thompson, Harlaxton Medieval Studies (Stamford: Paul Watkins, 1999), 48-50.

${ }^{103}$ Examples include John Blair, "Anglo-Saxon Minsters" Pastoral Care Before the Parish; Blair, Minsters and Parish Churches: The Local Church in Transition, 950-1200. (Oxford: Oxford University Committee for Archaeology, 1988), 226-266; Catherine Cubitt, Anglo-Saxon Church Councils c. 650-c. 850, Studies in the Early History of Britain (London: Leicester University Press, 1995), 115-120; John Godfrey. "The Place of the Double Monastery in the Anglo-Saxon Minster System" in Famulus Christi: Essays in Commemoration of the Thirteenth Centenary of the Birth of the Venerable Bede ed. Gerald Bonner (London: SPCK, 1976), 346; David Rollason, "Monasteries and Society in Medieval Northumbria," in Monasteries and Society in Medieval Britain: Proceedings of the 1999 Harlaxton Symposium, ed. Benjamin Thompson (Stamford, Lincolnshire: P. Watkins, 1999), 59-74.
} 
episcopal system, was the basis for pastoral care in Britain at this time. Blair summarized the argument as such:

The older and more important churches housed religious communities which, though varying greatly in size, wealth, and religious complexion, were known as 'minsters' (monasteria); minsters exercised rights over defined territories (the later 'motherparishes') which they came to provide with pastoral care... ${ }^{104}$

Minsters and episcopal authority should not be seen as incompatible, but rather as "overlapping structures." 105 The monasteria at this time were widely varied in character, size and the activities in which they engaged and it is a mistake to read Benedictine regularity into the seventh century evidence. ${ }^{106}$ This is evident is Bede's description of the monastery of Lindisfarne in which he describes the pastoral practices of monks and clerics.

The sole concern of these teachers was to serve God and not the world, to satisfy the soul and not the belly. For this reason the religious habit was held in great respect at that time, so that whenever a cleric or a monk went anywhere he was gladly received by all as God's servant. If they chanced to meet him by the roadside, they ran towards him and, bowing their heads, were eager either to be signed with the cross by his hand or to receive a blessing from his lips. Great attention was also paid to his exhortations, and on Sundays the people flocked eagerly to the church or the monastery, not to get food for the body but to hear the word of God. ${ }^{107}$

The monks described in this passage were engaged in some sort of pastoral care and that a monastic institution might contain both monks and priest for whom ministering was a

\footnotetext{
${ }^{104}$ John Blair, "Debate: Ecclesiastical Organization and Pastoral Care in Anglo-Saxon England," Early Medieval Europe 4, no. 2 (1995), 193-212: 193.

${ }^{105}$ Cubitt, Anglo-Saxon Church Councils C. 650-C. 850, 113.

${ }^{106}$ Foot, "Anglo-Saxon Minsters: A Review of the Terminology," in Pastoral Care before the Parish, ed. John Blair and Richard Sharpe (Leicester; New York: Leicester University Press, 1992), 225.

${ }^{107} H E$ III. 26
} 
priority. ${ }^{108}$ This passage may be an idealized conception of what Bede thought should happen, but it nevertheless shows that Bede accepted that such a role was possible.

Aldhelm also offers us a glimpse into the administrative and pastoral demands that were placed upon monasteries. At the end of the De Virginitate Aldhelm apologizes for both the brevity of his work and its delay by saying that he was: "weighed down with the burden of pastoral care and overwhelmed with the weight of worldly business, (and) because the demanding responsibilities of ecclesiastical administration did not allow any space of undisturbed peace and a leisured interval for writing, and the noisy bustle of practical matters interrupted it." 109 Furthermore, charter evidence shows that as late as 676 minsters were being founded explicitly to meet the pastoral needs of a region. ${ }^{110}$ The penitential attributed to Archbishop Theodore deals with the problems of replacing the priests that served an area if the minster has been relocated: "if anyone wishes to set his monastery in another place, he shall do it on the advice of the bishop and of his brethren, and he shall release a presbyter for the ministry of the church in its former place."111 Moreover, Bede mentions that episcopal sees were largely vacant at this time. The bishopric at Rochester is specifically mentioned as having "long been vacant." 112 Considering the evidence for pastoral care being provided by monasteries and the lack of episcopal authority, it seems appropriate to view the monasteries as having fulfilled pastoral duties.

\footnotetext{
${ }^{108}$ Blair, "Debate: Ecclesiastical Organization and Pastoral Care in Anglo-Saxon England," 208. ${ }^{109}$ De Virginitate LIX.3 pastoralis curae sarcina gravatus negotiorumque terrenorum ponderibus oppressus ita perniciter, ut sategistis, dictarevobisque destinare nequverim, quia securae quietis spatium et morosam dictandi intercapidinem scrupulosa ecclesiastici regiminis sollictudo denegabat et tumultuans saecularium strepitus obturbabat.

${ }^{110}$ Patrick Sims-Williams, "St. Wilfrid and Two Charters Dated AD 676 and 680," Journal of Ecclesiastical History 39, no. 163-83. (1988): 167-174.

${ }^{111}$ Poenitentiale Theodori II. 6.7

${ }^{112}$ HE IV.2
} 
As the monasteries were often founded by the high nobility and endowed with very substantial grants of land, it is not surprising that they would be led by a notable member of the society. An example of the size that monastic institutions could reach can be seen from the grant made by King Aethelwalh of Sussex to Wilfrid for a monastery at Selsey. Wilfrid was granted eighty-seven hides of land ${ }^{113}$ at a time when the entire kingdom of Sussex contained only seven thousand hides. ${ }^{114}$ The royal family, in particular, was often closely affiliated with the larger monastic foundations. One example of this pattern is that King Wulfhere of Mercia's three sisters were all placed as the first abbess of a double monastery as part of system of monastic expansion in the late seventh century. ${ }^{115}$ The Mercian kings also seem to have pursued a pattern of patronizing monasteries in an attempt to expand their influence. Monasteries at Chertsey, Barking, Abingdon, and Malmesbury all were given sizeable grants during the seventh century. ${ }^{116}$ Chertsey, for example, was granted over two hundred hides by a sub-king of Mercia while Barking received forty hides from a relative of Sebbi, king of the East Saxons. ${ }^{117}$ Monastic institutions, double or otherwise, were clearly important landholders. The land used to found double monasteries often seems to have been the result of royal grants. However, this was not always the case. There are at least two examples of

\footnotetext{
${ }^{113}$ HE IV.4 A hide is roughly equivalent to the amount of land that could support one household.

${ }^{114}$ Peter Hunter Blair, An Introduction to Anglo-Saxon England, (Cambridge,: Cambridge University Press, 1977), 148.

${ }^{115}$ John Blair, "Minster Churches in the Landscape," 39.

${ }^{116}$ Barbara Yorke, Kings and Kingdoms of Early Anglo-Saxon England (London: Routledge, 1997), 110.

${ }^{117}$ Dorothy Whitelock, ed. English Historical Documents C. 500-1042 (London: Eyre and Spottiswoode, 1968), 440-1, 447-8.
} 
abbesses purchasing large tracts of land on which to found their monasteries. Bede's description of the monastic career of Hild of Whitby is one example of how monastic institutions were endowed. Hild was a member of the Northumbrian royal family and did not enter the monastic life until she was thirty-three. ${ }^{118}$ While she first considered joining a monastery in Gaul, Bishop Aidan convinced her to stay in Northumbria and was given "a hide of land on the north side of the river Wear." abbess of Hartlepool where she ruled for some years. After two years she then bought ten hides of land to found her own double monastery at Whitby. ${ }^{120}$ Hild's position of influence was a direct result of her membership in the Northumbrian royal family, which continued after she entered the monastic life and she was able to purchase her own land well into her monastic career. A second example of an abbess purchasing her own land is where the Kentish queen Seaxburg is shown to have bought the land for her monastery at Sheppey. ${ }^{121}$ The abbesses who ruled in the double monasteries were royal and noble women who, upon leaving their influential secular positions of power, seem to have maintained their positions in society after taking on the position of abbess.

The organization and structure of the monasteries could also follow along familial lines. Sarah Foot has recently argued that Anglo-Saxon monasteries can best be understood as religious families. She contends that they were "so well integrated into early Germanic kinship structures that they appear markedly similar to contemporary

\footnotetext{
${ }^{118} H E$ IV.23.1

${ }^{119}$ HE IV 23.3

${ }^{120} \mathrm{HE}$ III. 24.3

${ }^{121}$ Stephanie Hollis, "The Minster-in-Thanet Foundation Story," Anglo-Saxon England 27 (1998), 41-64: 47.
} 
secular social groupings, most notably to aristocratic households."122 This affinity is not at all surprising considering the noble lineage of the abbesses. In theory, the religious family replaced the secular family that was being abandoned. However, it seems clear that the social hierarchies of the world outside of the monastery were still quite powerful even after one entered the religious community. ${ }^{123}$ In fact, Patricia Coulstock has argued that the double monastery was simply an extension of the royal family's political power. ${ }^{124}$ She goes on to say that the double monastery functioned as a power base for the royal women. While this is certainly true, the close association between the familial organization of the double monastery and the position of women can be problematic.

The most often cited passage regarding the role of abbess in the double monastery is from Joan Nicholson. She states that the double monastery "provided the female element of the ruling class with something to rule." ${ }^{25}$ Certainly, royal women did occupy these positions of power. However, it is her inclination to view the double monastery as merely an outlet for these assertive women that is problematic. Envisioning the double monastery as merely an "avenue for occupation for meddlesome women" obscures the powerful positions held by these royal women before they entered the monastery and also imagines these monasteries as being of secondary importance. ${ }^{126}$ Such an important institution needed to be managed by capable individuals and could not

\footnotetext{
${ }^{122}$ Foot, "Role of the Minster," 39.

${ }^{123}$ Foot, "Role of the Minster," 42-3.

${ }^{124}$ Patricia Coulstock, The Collegiate Church of Wimborne Minster (Woodbridge: Boydell, 1993).

${ }^{125}$ Nicholson, "Feminae Gloriosae: Women in the Age of Bede," 18.

${ }^{126}$ Nicholson, "Feminae Gloriosae: Women in the Age of Bede," 29.
} 
simply be a token field of authority to placate royal women. These royal women did not need to be given something to rule as they had this authority in secular affairs. ${ }^{127}$

The familial structure of the monasteries during this period makes it tempting to see the abbess as a maternal figure. Clarissa Atkinson has argued that it was the identification of the abbess as 'mother' that carried "overtones of profound respect, almost awe, in the writings of men whose stories celebrated holy virgins who presided over communities of women, and even men." 128 Bede states that "all who knew Hild, the handmaiden of Christ and abbess, used to call her mother." ${ }^{29}$ The placing of abbatical authority under the guise of motherhood was in many ways very damaging to female authority. The adoption of maternal imagery has the effect of essentializing the physical sex of the woman. Furthermore, as Felice Lifshitz has noted, respect for spiritual maternity does not indicate respect for maternal authority. ${ }^{130}$

To assert that female religious superiors based their authority instead on maternality would be problematic. Although many scholars have considered mothers to have been responsible, during the period covered by this essay, for the moral and religious upbringing of their children, even the strongest scholarly statement of the maternal responsibility to nurture does not assert any maternal authority to command. ${ }^{31}$

However, contemporary models that envisioned the authority of the abbess as essentially maternal are certainly present as Bede's description of Hild attests. It was not, however,

\footnotetext{
${ }^{127}$ Fell, Women in Anglo-Saxon England. Wemple, Women in Frankish Society: Marriage and the Cloister, 500 to 900 .

${ }^{128}$ Clarissa Atkinson, The Oldest Vocation: Christian Motherhood in the Middle Ages (Ithaca, New York: Cornell University Press, 1991), 95.

${ }^{129}$ HE IV.23.6.

${ }^{130}$ Felice Lifshitz, "Is Mother Superior?: Towards a History of Feminine Amtscharisma," in Medieval Mothering, ed. John Carmi Parsons and Bonnie Wheeler (New York and London: Garland Publishing, Inc., 1996), 117-138: 119,121,128.

${ }^{131}$ Lifshitz, "Is Mother Superior?" 119. Emphasis is from the original author.
} 
the only option available for thinking about the exercise of authority by women at this time.

Lifshitz's analysis of two attempts to provide female monastic rules in the seventh century is useful for understanding the options for female monastic authority at this time. ${ }^{132}$ These rules are Gallic in origin, not Anglo-Saxon but owing to the continental influence on monastic development in Britain, they may help us give insight into these issues. These rules were both derived from the Benedictine rule and covered similar themes. Bishop Donatus of Besançon wrote the first example of such a rule around the middle of the seventh century. ${ }^{133}$ In this rule, Donatus replaced the Benedictine abbot who is presented as a preeminent father figure, with an impotent motherly abbess who is not to be obeyed, but rather to be loved. ${ }^{134}$ Donatus chooses to replace Benedict's term for the abbot, abbas, with mater and removes the ability for the abbess to discipline her subordinates from his rule. Such a system clearly did not envision an abbess as being suitable, or perhaps able, to wield 'masculine' authority.

This rule can be contrasted with an anonymous rule for female monastics composed in the seventh or eighth century which shows one way that women might be included into a male centered view of authority. This "rule of the abbess" was based upon the Benedictine rule but replaced the abbot with the term abbatissa, a female father. ${ }^{135}$ However, unlike Donatus, the author of this rule maintained the strong position of authority for the abbess despite the fact that she was female.

\footnotetext{
${ }^{132}$ Lifshitz, "Is Mother Superior?," 125-128.

${ }^{133}$ Regula ad virgines, $P L$ 87, 273-298.

${ }^{134}$ Lifshitz, "Is Mother Superior?," 126.

${ }^{135}$ Lifshitz, "Is Mother Superior?," 126-128.
} 
By feminizing the masculine noun abbas, the author of this rule was able to place the women into a view of authority that saw the ability to command as essentially a masculine characteristic. While this view is egalitarian in the sense that it does not view male and female experience as substantially different, it may be seen as having the effect of seeing such women as second-class males. ${ }^{136}$ Carol Clover has recently shown that such a conception of power did not preclude men and women from accessing traits that might be construed as predominately masculine or feminine in early Northern Europe. ${ }^{137}$ Through an analysis of Scandinavian literary sources, Clover argues that the modern conception of men and women as being biological opposites did not necessarily exist at this time. She has identified a "one-sex social logic, a one gender model" that existed in early northern Europe. ${ }^{138}$ Attributes of masculinity and femininity were not permanently fixed upon biological sex, but rather were ascribed to individuals based upon their conduct. A woman might be seen as having certain masculine traits if she acted in a similar fashion ${ }^{139}$ Likewise, a man who acted weakly, or lacked agency, such as the old and infirm would be described by using adjectives that indicated his femininity. As Clover states, "the general notion, that sexual difference used to be less a wall, than a permeable membrane, has a great deal of explanatory force in a world in which a physical woman could become a social man, a physical man could (and sooner or later did) become a social woman."140

\footnotetext{
${ }^{136}$ Lifshitz, "Is Mother Superior?," 127-131.

${ }^{137}$ Carol Clover, "Regardless of Sex: Men, Women, and Power in Early Northern Europe," Speculum 68, no. 2 (1993), 363-387.

${ }_{138}$ Clover, "Regardless of Sex," 386.

${ }^{139}$ Clover's description of a wife defending her husband from bounty hunters is one such example.

${ }^{140}$ Clover, "Regardless of Sex," 387.
} 
Such a system might also be useful to understand the ways in which other northern Europeans approached the issue of gender and female authority. Janet Nelson has shown that the Merovingian queens Brunhild and Balthild were quite powerful and were able to function as effective leaders in their own right. ${ }^{141}$ Significantly, they are both presented with masculine traits. "Brunhild defied a posse of armed enemies viriliter'like a man' - while to Balthild was attributed that most manly of virtues - strenuitas." 142 This type of evidence is not limited to the early medieval period. Examples of female lordship from the twelfth century show that such figures as Adela of Blois and Blanche of Navarre were able to function as powerful aristocratic figures. ${ }^{143}$ Kimberly LoPrete has argued that "women exercised more acknowledged power than has been assumed and that accounts of medieval politics are incomplete if they ignore the deeds of female lords."144

Similar evidence for Anglo-Saxon female lordship can be found in the Boniface Correspondence. ${ }^{145}$ Christine Fell's analysis of the famous letter from Lull, Denehard and Burghard to the abbess Cyniburg ${ }^{146}$ shows that abbesses equally participated in the Anglo-Saxon legal system that demanded travelers be under a lord who would take responsibility over them. ${ }^{147}$ Lull, Denehard and Burghard told Cyniburg that if they

\footnotetext{
${ }^{141}$ Janet Nelson, "Queens as Jezebels: The Careers of Brunhild and Balthild in Merovingian History," in Medieval Women, ed. Derek Baker (Oxford: Blackwell, 1970), 31-77.

${ }_{142}$ Nelson, "Queens as Jezebels: The Careers of Brunhild and Balthild in Merovingian History," 76.

${ }^{143}$ Theodore Evergates, "Aristocratic Women in the County of Champagne," in Aristocratic Women in Medieval France, Theodore Evergates, ed. (Philadelphia: University of Pennsylvania Press, 1999), 75-110. ${ }^{144}$ Kimberly LoPrete, "Adela of Blois: Familial Alliances and Female Lordship," in Aristocratic Women in Medieval France, ed. Theodore Evergates (Philadelphia: University of Pennsylvania Press, 1999), 8-43: 43. ${ }_{145}$ Tangl, ed. Die Briefe des Heiligen Bonifatius und Lullus.

146 Tangl, ed. Die Briefe des Heiligen Bonifatius und Lullus, 78-80.

${ }^{147}$ Fell, "Some Implications of the Boniface Correspondence," 33.
} 
visited Britain they would place themselves under her guardianship and no other. ${ }^{148}$ Later in the same letter, they request that she protect two recently freed boys and to make arrangements for them if she is acting as their lord. ${ }^{149}$ Fell argues convincingly that "since they have been freed, tua potestate self-evidently does not mean they might be 'in her power' in the sense of slavery, but must clearly mean that she functions as their hlaford, their 'lord.",150 If an abbess functioned as the lord and protector of these prestigious men then we should understand her as a domina in its grammatical sense as a 'female lord.' The term used in the correspondence would seem to show a more egalitarian conception of authority which allowed for the expression of power by women. We seem to be presented with two different views on female authority. There is significant evidence to show a pattern of female lordship. However, Bede would seem to view the powerful Hild as essentially a maternal figure and consistently marginalized women in his account of the Anglo-Saxon church. The question then becomes which evidence are we to understand as central to seventh century views on gender and which should be considered liminal.

There are two main problems with using Bede to understand conceptions of gender in the seventh century. First, Bede's descriptions of the role of women do not seem to reflect the prominent roles that noble women played at this time. Stephanie Hollis has argued that:

Given the actual power and influentiality of royal abbesses and queens, Bede's near silence on the activities of reigning queens and his scanty,

\footnotetext{
${ }^{148}$ Tangl, ed. Die Briefe des Heiligen Bonifatius und Lullus, 79. nullius hominis oboedientiam et institutionem antea quęrimus, quam tuae bonevolentiae subiectionem, quia in te firmissimam spem mentis nostrae positam habemus

${ }^{149}$ Tangl, ed. Die Briefe des Heiligen Bonifatius und Lullus, 79-80. in tua potestate sint

${ }^{150}$ Fell, "Some Implications of the Boniface Correspondence," 33.
} 
unforthcoming coverage of the double monasteries assumes a meaningful aspect... ${ }^{151}$

Likewise, David Kirby has characterized Bede's views as essentially "idiosyncratic" due to his idealization of the past. He argues that many of his contemporaries would not "necessarily discern in the pages of the Ecclesiastical History an image of the Northumbrian Church which they could recognize as a valid reflection of their own experience." 152 One of the most insightful analyses is that of Kathleen Biddick in her essay "Bede's Blush: Postcards from Bali, Bombay, Palo Alto."153 By placing Bede in the multi-lingual world of Britain at this time, we can begin to understand the tensions that are implicit in his text. We need to understand how Bede's text "works as a gobetween among Mediterranean, Anglo-Saxon, and Celtic churchmen"' in order to piece together why he presented female power in the way that he did.

I would argue that Bede characterized Hild's respect and influence as maternal due to the influence exerted by the influx of Mediterranean religious practice into Britain in the seventh century. Bede's predilection for things Roman is well known. ${ }^{154}$ The basic emplotment of the Historia Ecclesiastica is to record the salvation of the British church through the intercession of Roman missionaries. Bede's reason for constructing his work in the way was not to record a historical account, but rather as a commentary on

${ }^{151}$ Hollis, Anglo-Saxon Women and the Church, 13. see also Clare Lees and Gillian Overing, "Birthing Bishops and Fathering Poets: Bede, Hild and the Relations of Cultural Production," Exemplaria, (1994), 35-66.

${ }^{152}$ Kirby, "Bede's Historia Ecclesiastica Gentis Anglorum: Its Contemporary Setting," 919. Kirby's work deals primarily with the political implications of Bede's recommendations concerning the foundation of additional bishoprics but further reinforces the marginality of Bede's viewpoint.

${ }^{153}$ Kathleen Biddick, "Bede's Blush: Postcards from Bali, Bombay, Palo Alto," in The Shock of Medievalism (Durham: Duke University Press, 1998), 82-101.

${ }_{154}$ e.g. James Campbell, "Bede II," in Essays in Anglo-Saxon History (London: Hambledon Press, 1986), 29-48. A recent discussion of the depth of Bede's leanings towards the Roman model of Christianity can be found in Judith Lamm Beall, "Bede and Irish Monasticism" (Dissertation: University of Califormia, Berkeley, 1997). 
the church. ${ }^{155}$ Bede describes Theodore's arrival in Britain in the most glowing terms. Bede states: "Never had there been such happy times since the English first came to Britain." 156 This moment where true Roman authority returns to Britain is critical for Bede's narrative where the lack of 'Romaness' is equated with disaster and ruin. ${ }^{157}$ The key to Bede's interpretive strategy towards women, which tends towards the essentialization of their sex, can be found in the ideas brought by Theodore's mission.

\section{Challenge}

Despite the influential and accepted position of double monasteries and of women in general in seventh-century England, both encountered a significant threat to their position and authority. This challenge came from the arrival of Theodore of Tarsus as Archbishop of Canterbury in $669 .{ }^{158}$ Bede notes that he was born in Cilicia in 602, and was trained in both Greek and Latin. Theodore most likely received his education in the schools of Antioch, or at the very least was heavily influenced by the Antiochene exegetical method. ${ }^{159}$ The philological influence of the Antiochene school, which

${ }^{155}$ e.g. Goffart, The Narrators of Barbarian History (A.D. 550-800): Jordanes, Gregory of Tours, Bede, and Paul the Deacon, 235-328. Kirby, "Bede's Historia Ecclesiastica Gentis Anglorum: Its Contemporary Setting."

${ }^{156}$ HE IV.2.1 He similarly champions Wilfrid for his support of Roman traditions at the Council of Whitby. HE III. 25

${ }^{157}$ The entire first book the $H E$ may be read in light of the rising or falling fortunes of the English depending upon their connection to Rome or the Roman church. ${ }^{158}$ HE IV.1

${ }^{159}$ Michael Lapidge, "The Career of Archbishop Theodore," in Archbishop Theodore: Commemorative Studies on His Lıfe and Influence, ed. Michael Lapidge (Cambridge: Cambridge University Press, 1995), 129: 4-6. 
emphasized literal and historical interpretation of scripture, can be seen from the biblical commentaries recently attributed to Theodore. ${ }^{160}$

Theodore's path to becoming Archbishop of Canterbury was a circuitous one. He was exiled from Syria as a result of the seventh-century Arab invasions and possibly spent time in Constantinople before taking up residence in a monastery near Rome. ${ }^{161}$ Michael Lapidge has argued that, while at this monastery, Theodore either became involved in theological disputes between the emperor and the pope over the monothelete controversy or, at the very least, was heavily influenced by the dispute over correct practice. ${ }^{162}$ These issues were of no small matter. The pope in this case, Martin I, was eventually tried for treason in Constantinople and, refusing to recant, had his hand cut off and his tongue cut out to prevent his writing or speaking further on the matter. One might understand then, that due to his likely involvement in these charged disputes Theodore's appointment to archbishop was initially delayed because of political concerns by the succeeding pope. Even when the choice was made the pope appointed Hadrian, a Roman abbot, to supervise Theodore in his new position. He did this "to prevent Theodore from introducing into the church over which he presided any Greek customs which might be contrary to the true faith." ${ }^{163}$ It is not surprising then considering this background that issues of orthodoxy would be predominate in Theodore's early career in Britain.

${ }^{160}$ Bischoff and Lapidge, eds. Biblical Commentaries from the Canterbury School of Theodore and Hadrian.

${ }^{161}$ Bischoff and Lapidge, eds. Biblical Commentaries from the Canterbury School of Theodore and Hadrian, 41-64.

${ }^{162}$ Bischoff and Lapidge, eds. Biblical Commentaries from the Canterbury School of Theodore and Hadrian, 77-81.

${ }^{163} H E$ IV 1.3 While this comment may be interpreted as Bede raising the specter of Theodore's potential unorthodoxy, I would prefer an alternate explanation. The most natural criticism of a foreign archbishop from the eastern Mediterranean would seem to be that he might in fact introduce unorthodox elements into the British church. However, by presenting Hadrian as overseeing Theodore's orthodoxy, Bede is 
Theodore began his tenure as the Archbishop of Canterbury (668-690) with a tour of Britain to assess the current state of the church. He promptly set about a proper reform of both the monasteries and bishoprics of the English Church. While Bede presents Theodore as taking an interest in giving instruction on the correct "ordering of a holy life... and the canonical custom of celebrating Easter"164 the greater emphasis is immediately placed upon Theodore's campaign to appoint a series of new bishops. ${ }^{165}$

At the time of Theodore's arrival over half of the bishoprics of Britain were not filled and his own see had been empty for almost five years. He immediately addressed the shortage by appointing several new bishops and by deposing those who refused to go along with his administrative reforms. ${ }^{166}$ He then sought to consolidate his organization and episcopal authority through annual synods of the bishops. ${ }^{167}$

These actions to strengthen episcopal administration should perhaps be viewed as a direct conflict between a monastery based system of ecclesiastical administration and an episcopal one. The fact that over half of the bishoprics were not filled lends credence to Blair's notion that monasteries were the administrative centers. The large number of vacancies in episcopal sees can be compared to flourishing monastic communities which had only decades before expanded across Gaul and Britain. ${ }^{168}$ The vast land holdings of such institutions and their political connections to the royal families of Britain represent a stark contrast to the relatively few bishoprics which had been so recently neglected.

insulating him from this very charge. As Hadrian is never shown objecting to Theodore's reform program, Theodore's action must therefore be orthodox.

${ }^{164} H E$ IV.2.1

${ }^{165} H E$ IV.2-3

${ }^{166} H E$ IV.6, 12 Bischoff and Lapidge, eds. Biblical Commentaries from the Canterbury School of Theodore and Hadrian, 133-134. Mynors, ed., 191.

${ }^{167}$ HE IV.5.9

${ }^{168}$ Campbell, "The First Century of Christianity in England," 61-62. Foot, Veiled Women I: The Disappearance of Nuns from Anglo-Saxon England (Aldershot: Ashgate, 2000), 38-39. 
Those bishops that did have substantial resources, such as Wilfrid, were too few to be able to function as an effective administrative organization in and of themselves. We should not necessarily follow Bede's lead in assuming that simply because episcopal authority was lacking that there was no effective ecclesiastical administration taking place. As we have seen from Blair's argument above, the numerous, powerful, and well connected monasteries could have performed this task and likely did so.

Blair proposes an interpretation that would view episcopal and monastic institutions as working in harmony. ${ }^{169}$ However, I would argue that Theodore's actions to appoint bishops to vacant sees and to split large sees into smaller ones should not be viewed as filling an administrative void, but rather as establishing a competing administrative system. To establish an episcopal administrative system meant that both land and authority would have to be wrested away from monasteries. Bede laments in his letter to Bishop Egbert that the foundation of new bishoprics would be hampered by the excessive royal grants made to monasteries. ${ }^{170}$ While Bede's letter is dated from 734 , there is no reason to believe that a similar problem did not confront Theodore. The vast tracts of land given to monastic institutions in the seventh century ${ }^{171}$ would have likely made attempts to vastly expand the number of bishops difficult. Bede's proposed solution to this problem was to place bishops into monasteries themselves and to confiscate the

\footnotetext{
169 John Blair, "Minster Churches in the Landscape," 38-39.

${ }^{170}$ Epistola ad Ecgberctum Antistitem 9. Charles Plummer, ed. Venerabilis Baedae Historiam Ecclesiasticam Gentis Anglorum. Historiam Abbatum, Epistolam Ad Ecgberctum, Una Cum Historia Abbatum Auctore Anonymo, Ad Fidem Codicum Manuscritorum Denuo Recognovit, 2 vols., vol. 1 (Oxford: Oxford University Press, 1896), 405-23; translated Whitelock, ed. English Historical Documents C. 5001042, 735-45.Et quidem novimus quia per incuriam regum praecedentium donationesque stultissimas factum est, ut non facile locus vacans ubi sedes episcopalis nova fieri debeat, inveneri valeat. ${ }^{171}$ c.f. pp 28-29.
} 
lands of monasteries that did not follow orthodox practice. ${ }^{172}$ Furthermore, if to establish episcopal control meant confiscating monastic property, then Theodore had every motivation to find certain monasteries as heterodox. Since the double monastery was the preferred type of monastery, it was this institution that Theodore logically needed to confront.

One of the ways that monastic authority was challenged was by questioning the mixing of the sexes in the double monastery. Theodore directly attacked the basis for the double monastery by proclaiming "it is not permissible for men to have monastic women, nor women men." $" 173$ This was a clear assault on the dual nature of the double monastery. Further evidence that carnality was a predominate concern for monastic institutions can be seen in another regulation in Theodore's penitential where he discusses whether it is suitable to consecrate widows and virgins together. ${ }^{174}$ Finally, Theodore also seems to have specifically reinforced this division between virgins and widows on occasion by using the term sacra virgo as a synonym for a female monk. ${ }^{175}$

This close association of physical purity represented a serious challenge to the double monastery on a number of different levels. First, questioning the basic assumption that spiritual men and women could form effective partnerships casts doubt on the 'purity' of double monasteries which would therefore lessen its institutional legitimacy. Furthermore, by attempting to divide the local aristocracy along gendered lines, he would be able to weaken the natural opposition to an increase in episcopal

\footnotetext{
${ }^{172}$ Epistola ad Ecgberctum Antistitem 10.

${ }^{173}$ Poenitentiale Theodori II.6.8

${ }^{174}$ Poenitentiale Theodori II.3.7

${ }^{175}$ Poenitentiale Theodori 1.8.7. Theodore's emphasis on physical purity will be discussed at greater length in chapter three.
} 
power all the while asserting that the program was merely to implement orthodox belief into England. ${ }^{176}$

The critical element of this challenge rests in the notion that regards gender as essentially physical. As long as spiritual worth was seen as the necessary quality for religious authority, women could access such power as well as men. However, if bodily purity were valued, then the women who led the double monasteries, who were often divorced, would be put at a serious disadvantage.

This challenge to the double monastery has sometimes been seen as uniformly successful. Hollis argues that it was this 'Roman-Christianity' that led to the assimilation of "a number of new conceptions of relationships and identity, and among these was a gender-specific identity for women." She argues further that "the alterization of women" can be seen as a virtual index of the degree to which Roman-Christianity was adopted. ${ }^{177}$ However, it need not be the case that an acceptance of Mediterranean scholarship and traditions would necessarily lead to viewing women as 'other.' To do so is to imagine the church as much more unified and focused in intent than is reasonable to assume. It seems likely that the arrival of Theodore and his campaign to change the very social and political fabric of society might not have received nearly as warm a welcome as Bede would have us believe. Might we profit from an attempt to locate areas of dissent that would support the ways that Anglo-Saxon society imagined itself? Such a response to this challenge must take into account the basic charge that men and women could not coexist as that seems to be one of the ways that Theodore attempted to divide the double

\footnotetext{
${ }^{176} \mathrm{I}$ am indebted to Prof. Kathleen Biddick for valuable discussion on this point.

${ }^{177}$ Hollis, Anglo-Saxon Women and the Church, 10,11.
} 
monastery. An answer would need to address the essential thesis that the physical sex of men and women made it impossible to form practical associations in a religious context. It is my contention that Aldhelm's De Virginitate is just such an argument. The final section of this paper will make this argument through a close analysis of the text of the De Virginitate. However, before we can proceed to the De Virginitate itself an examination of the theoretical background towards the religious association of men and women that formed the basis for both Theodore and Aldhelm's thought is necessary. We cannot come to an adequate understanding of Aldhelm's work if we imagine him working in isolation from Theodore. Aldhelm studied at Theodore and Hadrian's school on two separate occasions sometime between 669 and $675 .{ }^{178}$ Furthermore, Aldhelm clearly supports the Roman cause in letter in which he states that "he who does not follow the teaching and rale of St. Peter boasts vainly and idly about his Catholic faith."179 Aldhelm is not a revolutionary opposing the influx of Roman traditions. Rather, I propose a reading of Aldhelm that envisions him attempting to balance these new traditions with the current social practices of Britain. However, in order to accomplish this task Aldhelm needed to maintain his own orthodoxy within this new tradition. He set about this by firmly grounding his work in sources whose authority could not be questioned. It is to these sources that we now turn.

${ }^{178}$ Aldhelmi et ad Aldhemvm Epistvlae 2 Ehwald, ed. Opera, 478. Since it seems that Aldhelm studied there before he became an abbot (c. 673-75), his studies at the Canterbury school can be safely dated between Theodore and Hadrian's arrival and Aldhelm's abbacy.

${ }^{179}$ Aldhelmi et ad Aldhemvm Epistvlae 4 Ehwald, ed. Opera, 480-486. frusta de fide catholica et incaniter gloriatur, qui dogma et reularum sancti Petri non sectatur 


\section{Chapter 3}

The positions taken by Aldhelm and Theodore toward double monasteries were adopted in the context of both local political concerns and long standing theological traditions. Their respective stances regarding gender relations had clear social and political ramifications. Theological debates were one of the battlefields upon which these issues could be decided. Just as both Theodore and Aldhelm came from widely different backgrounds, they utilized very different theological traditions. In order to develop the ways in which Theodore and Aldhelm used these traditions it is necessary to develop the most important sources to each author.

Aldhelm and Theodore each employed arguments that were based upon sources that were widely accepted as orthodox. Not surprisingly, Theodore seems to have based the majority of his theological positions upon Greek sources. Biblical commentaries attributed to Theodore cite Basil of Caesarea, Clement of Alexandria and John Chrysostom by name. ${ }^{180}$ Of these, Chrysostom seems to have been the most quoted and venerated over all other author. ${ }^{181}$ The sections of Aldhelm's De Virginitate, which deal most explicitly with issues that would pertain to the position of the double monastery, are heavily influenced by Augustine and Pope Gregory. This chapter will begin with an analysis of Theodore and Chrysostom's thought and will then move to an analysis of Augustine and Gregory's work as it influenced Aldhelm.

${ }^{180}$ Bischoff and Lapidge, eds. Biblical Commentaries from the Canterbury School of Theodore and Hadrian, 205-216.

${ }^{181}$ Bischoff and Lapidge, eds. Biblical Commentaries from the Canterbury School of Theodore and Hadrian, 214. Chrysostom is quoted by name seven times. For comparison, Basil of Caesarea and Clement of Alexandria are only mentioned once. 


\section{Theodore}

Theodore's entry into Britain in 669 accelerated the development of a singular orthodoxy within the Anglo-Saxon church. Theodore was instrumental in the attempt to establish a single orthodox belief. In so doing, he challenged the status quo of seventhcentury Britain. Perhaps the best source available to assess Theodore's beliefs is a penitential, or iudicia, that consists of answers to questions from an Irish priest, Eoda that was later edited by an anonymous discipulus Umbrensium. ${ }^{182}$ The work itself is composed of two books. The first book is a penitential proper and contains fifteen chapters of proscriptions for dealing with various sins. The second book contains fourteen chapters of canons that describe Theodore's rulings on a variety of issues. The work is not directly from Theodore but the ideas contained within the text have been held to be generally representative of Theodore's thought. ${ }^{183}$ Bernhard Bischoff and Michael Lapidge have argued that: "it is clear that one must exercise caution before accepting any statement in the Iudicia as Theodore's own. Nevertheless, there can be little doubt that it is principally Theodore's thought and learning which have shaped the collection." ${ }^{\text {"184 }} \mathrm{A}$ general survey of the issues in this work reveal Theodore was highly interested in both orthodox practice amongst the clergy and in ritual physical purity.

One such example of the concern for heresy acknowledges the presence of a large and active group of unorthodox congregations. This chapter contains fourteen

${ }^{182}$ Poenitentiale Theodori 2.4 .8

${ }^{183}$ Bischoff and Lapidge, eds. Biblical Commentaries from the Canterbury School of Theodore and Hadrian, 147-155. Gamer, ed. Medieval Handbooks of Penance, 180. Lapidge, "The Career of Archbishop Theodore," 17, 28.

${ }^{184}$ Bischoff and Lapidge, eds. Biblical Commentaries from the Canterbury School of Theodore and Hadrian, 151. 
proscriptions against communion with heretics, the need to rebaptize heretics and a prohibition against ordaining a heretic who has returned to the fold, except in great necessity. ${ }^{185}$ This would seem to suggest that orthodox practice was a primary concern. Furthermore, the penitential shows a high degree of concern for incompetent or misinformed clergy. ${ }^{186}$ There are frequent references to pagan practices such as the drinking of blood and semen and prohibitions against incantations that include the clergy. ${ }^{187}$

What is perhaps more interesting for our subject is the importance Theodore's penitential places upon physical purity. Immediately following the canon against consumption of blood, it is stated that "women shall not in the time of impurity enter into a church, or communicate---neither nuns nor laywomen." 188 Similarly, the biblical commentary attributed to Theodore also shows a distinct concern for the purity of the flesh. In a commentary on the book of Genesis, it is stated that at the time of menstruation it is not "permissible for anyone to touch her, but that someone may place food - and nothing else - before her, which she may accept until the blood ceases."189 The implication of this point might best be illustrated by contrast to Greogory's position on issues of purity regarding menstruation. Gregory answered Augustine of Canterbury questions regarding menstruating women by saying that they should not be barred from church as "this natural overflowing can not be considered a crime" they did

\footnotetext{
${ }^{185}$ Poenitentiale Theodori $1.5 .2,6$, and 7

${ }^{186}$ e.g. ibid., $1.56,2.2 .10$

${ }^{187}$ Ibid., $1.7 .3,1.14 .16,2.10 .5,1.15 .4$

${ }^{188}$ Ibid., 1.14 .17

${ }^{189}$ Bischoff and Lapidge, eds. Biblical Commentaries from the Canterbury School of Theodore and Hadrian, 334-5. Iuxta consuetudinem mulierum [XXXI.35]: i. menstrualem. Tunc/enim non est facilis cuilibet surgere uel ambulare; nec licet eam tangere alicui nisi ut cibum tantum quis ponat ante ipsam quae accipiat usque dum sanguis resistat.
} 
not willfully choose to menstruate. ${ }^{190}$ The distinction between these two canons is that Theodore's ruling is based upon physical nature while Gregory's prioritizes the spirit and the will. His ruling that baptism by a polluted presbyter was invalid can also show the degree to which Theodore emphasized physicality in penitential. ${ }^{191}$ This emphasis upon the physical is particularly relevant for the association of the sexes in mixed monasteries. It is this concern with physical failings that presumably leads the penitential to speak against the cohabitation of monastic men and women. ${ }^{192}$ As we shall see later, it is precisely this distinction between physical and spiritual purity that Aldhelm will seize upon in the De Virginitate.

\section{John Chrysostom}

Theodore was most likely influenced towards emphasizing physical purity by the work of John Chrysostom. The themes that Chrysostom develops are particularly important for understanding Theodore's approach to double monasteries. Theodore was almost certainly educated in Antioch and would have been quite familiar with Chrysostom's work at a young age. As noted above, Chrysostom is the most cited individual in his biblical commentaries. ${ }^{193}$ Careful attention to Chrysostom's thought then regarding sex, marriage, and gender relations will help us understand the ways in which

\footnotetext{
${ }^{190}$ HE 1.27 The Gregorian theme of "diversity within unity" is the subject of his Regula pastoralis and is developed there at length. See Robert Markus, Gregory the Great and His World (Cambridge: Cambridge University Press, 1997), esp. 72-75.

${ }^{191}$ Poenitentiale Theodori 2.2 .12

${ }^{192}$ Ibid., 2.7 .8

${ }^{193}$ Michael Lapidge, Archbishop Theodore: Commemorative Studies on His Life and Influence, Cambridge Studies in Anglo-Saxon England; 11 (Cambridge: Cambridge University Press, 1995), 3-6.
} 
Theodore may have thought about the double monasteries when he arrived at Canterbury, and by extension, the thought that Aldhelm was reacting against. Chrysostom's writing is especially relevant for this discussion as he wrote explicitly on the status of marriage and the cohabitation of monastic men and women in Antioch. ${ }^{194}$

According to Chrysostom, marriage originated as a direct result of the fall from Eden. Before the Fall, there was no need for marriage as there was no hint of sexual desire and men and women lived in a pure virginal state. "Desire for sexual intercourse, conception, labor, childbirth and every form of corruption had been banished from their souls. As a clear river shooting forth from a pure source, so were they in that place adorned by virginity."195 Marriage only arose after the Fall as a way to minimize lust. It had its value at this time, but Chrysostom argues that it was time to put away these 'childish' ways and to embrace perfect virtue. ${ }^{196}$ Marriage arose at the same time as all the other worldly institutions and all have the same effect.

Why did marriage not appear before the treachery? Why was there no intercourse in paradise? Why not the pains of childbirth before the curse? Because at that time these things were superfluous. The necessity arose later because of our weakness, as did cities, crafts, the wearing of clothes, and all our other numerous needs. Death introduced them in its wake. ${ }^{197}$

Chrysostom has linked sexuality to marriage in such a way that characterizes association with the opposite sex as essentially physical.

The only benefits of marriage were procreation and a salve for lust. Neither of these reasons is particularly convincing in Chrysostom's estimation. Procreation is

\footnotetext{
${ }^{194}$ Adversus eos qui apud se habent subintroductas virgines, Quod regulares feminae viris cohabitare non debeant, and his own De Virginitate

${ }^{195}$ De Virginitate (John) 14.3.6

${ }^{196}$ De Virginitate (John) chapters 15-17.

${ }^{197}$ De Virginitate (John) 15.2
} 
unnecessary as "the earth and sea and all the world has been inhabited." 198 While "marriage is of much use to those who are still now caught up in their passions," it is a relic of a bygone age. ${ }^{199}$ The emphasis here is on the revolutionary aspects of Christianity. Just as children eventually reach adulthood, Chrysostom sees Christian society as finally reaching the point where it can abandon marriage and hence, the need for men to associate with women and vice versa.

The large numbers of virgins and ascetics that Chrysostom saw around him were evidence that this change was taking place. His view of society was essentially a dualistic one. The previous worldly construction of society was being replaced by a spiritual one. Virginity was conceived in the Pauline sense as being physically removed from marriage. Formulating virginity in this way results in the removal of virgins' bodies from the traditional cycle of replenishing the population of the city. ${ }^{200}$ Virginity represents the triumph of Christianity over paganism and the emergence from a religious 'childhood.'

There will no longer be marriage or birth pains, sexual pleasure or intercourse, an abundance of money or the management of possessions, food or clothing, agriculture or seamanship, crafts or construction, cities or homes, but some other system and way of life. All of these will cease to exist in a little while. ${ }^{201}$

The characteristics of virginity that Chrysostom describes are based upon physicality rather than inner spirituality. In fact, holiness in this formulation is directly related to the degree to which one is removed from things of this world. Yet Chrysostom's thought itself is not wholly based upon physicality as he also states that physical aspects of

${ }^{198}$ De Virginitate (John) 19.1.5

${ }^{199}$ De Virginitate (John) 19.2.1

${ }^{200}$ Brown, Body and Society, chapter 1.

${ }^{201}$ De Virginitate (John) 73.4.9 
virginity had little or no meaning without the moral character that should be present to equal mere physical integrity. ${ }^{202}$ However, for Chrysostom, the issue of inappropriate behavior by virgins of the church seems to predominately be a public relations problem which could undermine his vision of Christianity in the multicultural world of Antioch. While he believes proper deportment by virgins to be essential to their status, the predominate aspect of his thought on the association between the sexes is a physical one.

Likewise, to begin his treatise directed against men cohabitating with virgins, Chrysostom set out the framework under which men and women theoretically can have personal contact. He defines two categories for association: marriage and prostitution. He reasons that marriage is valid since it is of "ancient origin and God was its legislator." Prostitution is the antithesis as it is not as ancient and was inspired by demons. This framework then leads up to his attack on a new arrangement, chaste marriage. This third practice, syneisaktism, is developed within Chrysostom's text to have a clear relationship with prostitution. ${ }^{203}$

This progression makes it quite clear that Chrysostom views the personal association between men and women to be inherently based upon sexual relations. While he is willing to excuse the problems associated with marriage because God ordained it as a method of procreation and reducing licentious desire, prostitution and syneisaktism have no such endorsement. Chrysostom does not explicitly accuse those practicing syneisaktism of engaging in sexual activity, but his constant sarcasm leaves little doubt as to his thoughts. He postulates that the men involved in syneisaktism "would not enjoy

${ }^{202}$ De Virginitate (John) 5.2

${ }^{203}$ Adversus eos 1.1 
such a despicable reputation nor would there be so many scandals, if a violent and tyrannical pleasure were not found in their cohabitation."204 For Chrysostom there can be no suitable reason for men choosing to live with women other than desire.

The essential premise of Chrysostom's thought concerning the association of men and women was dominated by an emphasis on physical sex. It is unsurprising that Theodore would adopt a similar viewpoint when confronted with the double monasteries in Britain. However, there is nothing essential about Christian tradition that necessarily compelled Theodore to do so. I have argued above that Theodore used this carnal understanding of gender relations in order to facilitate the delegitimization of monastic institutions for the purpose of establishing a competing system of episcopal control. Theodore chose to emphasize a particular strain of tradition that, while adhering to his own training, also had the practical benefit of furthering his administrative goals. An entirely different view might be constructed from other canonical sources.

\section{$\underline{\text { Paul and Augustine }}$}

The writings of Paul and Augustine are the most cited sources by Aldhelm for his theoretical elements in the De Virginitate. In regards to Paul, the most important works for Aldhelm were the letters Ephesians and I Corinthians. For Augustine, there are a number of direct citations and parallels of his work in the De Virginitate. ${ }^{205}$ Among the most influential for this work are the De Civitate Dei, De Bono Conjugali, and De Sancta

\footnotetext{
${ }^{204}$ Adversus, eos 1.2.9 The formation of a third gender is discussed in general terms in McNamara, Sisters in Arms: Catholic Nuns through Two Millennia, 144-147.

${ }^{205}$ J.D.A. Ogilvy, Books Known to Anglo-Saxon Writers from Aldhelm to Alcuin (670-804) (Cambridge: Medieval Academy of America, 1970).
} 
Virginitate. The influence of Augustinian thought upon Aldhelm should not be underestimated. In crafting his argument he makes prolific use of both Augustine's texts and the implications suggested by his theology. ${ }^{206}$

Paul's thought concerning virginity was based upon the distinction between the body and the spirit through the affirmation or rejection of the institution of marriage. While regarding virginity as valuable, it was not compatible with the institution of marriage. Framed in this manner, marriage is inherently linked to the sex act while virginity is the absence of marriage. The Pauline doctrine concerning this tension reaffirms the gospel notion of marriage while stressing the benefits of celibacy.

Paul begins his section on virginity and marriage in I Corinthians by stating that, though it would be best if everyone were able to hold to chastity as he did, not everyone was given the strength to do so. ${ }^{207}$ And for those married, to abandon the sexual contact was dangerous and would lead to sin, as the inherent lust would not be satisfied. ${ }^{208}$ While reiterating the prohibition on divorce,${ }^{209}$ Paul still expresses that virginity is preferable as long as it is not socially disruptive. ${ }^{210}$ This essentially conservative message may have been a "rearguard action" against the response his previous radical egalitarian teachings in the letter to the Galatians generated. ${ }^{211}$ Paul proclamation that "there is neither Jew nor Greek; there is neither slave nor free; there is neither male nor female" is a particularly

\footnotetext{
${ }^{206}$ While Ogilvy opines that it is "much safer to assume that the English knew any particular work of Augustine than they did not," for our purposes I will only include those that Aldhelm explicitly deals with in his text.Ogilvy, Books Known to Anglo-Saxon Writers, 15.

${ }^{207}$ I Cor. 7.7

${ }^{208}$ I Cor $7.8-11$

${ }^{209}$ I Cor. $7.10-11$.

${ }^{210}$ I Cor $725-40$

211 Brown, Peter. The Body and Society: Men, Women, and Sexual Renunciation in Early Christianity (New York: Columbia University Press, 1988), 53-57.
} 
destabilizing doctrine. ${ }^{212}$ While this doctrine might have been advisable to recruit members to a new religious faction, later in his career these egalitarian measures served to undercut the very households that were the basis for Paul's support. The message from Paul is thus explicitly an attempt to maintain the current social structure based upon a stable household. Virginity, while clearly not for all, is still a holier state than marriage. ${ }^{213}$ By focusing the dialogue in this manner, the end effect of these passages served to structure the discussion on virginity as a removal from the problematic nature of marriage, while equating marriage with sex.

Augustine's own philosophy towards virginity was also based upon the foundation of marriage, though it too was essentially socially conservative. ${ }^{214}$ The revolutionary aspect of Augustine's construction of marriage was that it removed the notion of sex as being fundamental to marriage. Rather, Augustine's view was that the essential nature of marriage was a matter of the will. Marriage was not formed through consummation, nor was it ended by impotence. This doctrine, formed in specific response to the debate between Jerome and Jovinian on virginity, ${ }^{215}$ is akin to Augustine's conception that the victim of a rape has not sinned because she did not consent. ${ }^{216}$ As virtue resides in the soul, as long as the will remains committed to holiness the chastity of the sufferer is never in question. Another may harm the body of a virgin but cannot touch

\footnotetext{
${ }^{212}$ Gal. 3.28

213 1 Cor. 7.7

${ }^{214}$ Elaine Pagels, Adam, Eve and the Serpent (New York: Random House, 1988), 113.

${ }^{215}$ Dyan Elliott, Spiritual Marriage: Sexual Abstinence in Medieval Wedlock (Princeton: Princeton University Press, 1993), 43.

${ }^{216}$ De Civitate Dei.16-18. PL XLI.13-804. This is directly quoted by Aldhelm near his conclusion Ehwald, ed. Opera, 319.
} 
their soul which remains pure. ${ }^{217}$ Aldhelm would utilize this precise construction of the superfluous nature of the outer body for use in his discussion of the relative merits of corporalis pudicitia and spiritualis castimonia.

Furthermore, Augustine rehabilitated sex itself. He postulated that Adam and Eve would have had "rational" sex in Eden according to their will if they had been able to remain there. ${ }^{218}$ Sex itself was not the problem; rather it was a contamination of the soul through separating the will from God that produced the error. For Augustine, the primary function of marriage resided in the stability and purity of the union. Marriage is beneficial, not just for the procreation of sons and daughters, but also for the social benefits as well. ${ }^{219}$ The greatest good in marriage comes from the disparagement of sexual relations in favor of the companionship and fruitful union.

Yet this union was still conditioned by the social context from which Augustine came. Augustine, despite his apparent compassion, could not see his way clear to a formulation of true spiritual companionship between men and women. ${ }^{220}$ His theory also had the effect of undermining the female ascetic's ability to match the male in sexual renunciation. If the fundamental spiritual problem does not reside in the body, then equal acetic practice could not lead to equal holiness. Rather, by fundamentally differentiating the sexes, Augustine enforced a gradation of relative worth.

\footnotetext{
${ }^{217}$ De Civitate Dei, 1.16.

${ }^{218}$ Elliott, 45.

${ }^{219}$ De Sancta Virginitate, 12.12 Habeant conjugia bonum suum, non quia filios procreant, sed quia honeste, quia licite, quia pudice, quia socialiter, procreant, et procreatos pariter, salubriter, instanter educant, quia thori fidem invicem servant, quia sacramentum connubii non violant.

${ }^{220}$ Elizabeth Clark, "Adam's Only Companion: Augustine and the Early Christian Debate on Marriage," Recherches Augustiniennes, 21 (1986): 139-162.
} 
Furthermore, Augustine also located the danger of sexual temptation within the female gender. Augustine's sexual past is well documented by his own hand. To a certain extent, this past may have given him a more compassionate view regarding sexual sins than was available to other more radical thinkers. Yet this relaxed view towards sexual morals does not indicate a positive view of sexuality in general. While Augustine accepted male sexuality, he still viewed women as both dangerous and corrupting of men. "Whether it is in a wife or a mother, it is still Eve (the temptress) that we must beware of in any women."221 It is clear that despite the implications of Augustine's location of sin within the will instead of the body, he still wished to keep traditional divisions between the status of men and women. Augustine stated that while women should experience the holy resurrection, there is no reason for a man to desire their presence in heaven. ${ }^{222}$

This negative view of women's sexuality led Augustine to accept the gospel formulation $^{223}$ that associated the virgin, widow and married women with the hundred fold, sixty fold, and thirty fold rewards. ${ }^{224}$ Despite Augustine's view that the physical body did not determine the holiness of a individual, there was a definitive hierarchy within the various states of virginity and chastity of women. In this context, the woman who has willed herself to be pure and remains bodily pure as well is the most holy. The widow whose will and body were at one time stained but whose will is now pure occupies the middle rank. Finally, the married woman who must embrace sexual activity occupies the final tier. As there are strict restrictions against divorce, there is little or no need to account for a woman who has willed to be free of her husband instead of having

\footnotetext{
${ }^{221}$ Ep. 243,10 in Brown, Peter Augustine of Hippo (Berkley: University of California Press, 1969), 63.

222 Elliott, 49.

${ }^{223}$ From Matt. 8.8 and Mk 4.8. Also see Ambrose, De Virginibus ad Marcellinam, PL XVI 187-232.

${ }^{224}$ De Sancta Virginitate. PL 40424
} 
been freed from the conjugal debt by the death of her spouse. Augustine's conception of the will defining marriage opens up new avenues for the interpretation of sexuality and purity. However, the potential benefits of this thought are limited by his need to respond to his Pelagian opponents. By being unable to see his way clear to envision a place for the competency and friendship of women, Augustine could not apply his theory of the will towards a compassionate understanding of marriage, and therefore virginity and chastity.

In sum, Paul's belief that marriage as a function of sexual activity makes it an appropriate foil for virginity. ${ }^{225}$ Within this context, virginity is clearly superior to marriage in a holy hierarchy. Augustine's formulation, however, brings about new possibilities for the construction of marriage, and therefore sex and virginity. By taking the position that marriage is based upon friendship and the will, the association of the relationship with sex in no longer predetermined. While he would later hedge this view during the course of the debates with the Pelagians, the theoretical framework for doing so was there and could be activated by later theorists. The traditional view of marriage that was closely associated with sex was balanced, to a certain degree, by Augustine's unexploited views that pointed towards the possibility of spiritual friendship between men and women. Aldhelm's dilemma was to find a path between the needs of Barking while remaining within the structure of received patristic tradition.

${ }^{225}$ Elliott, 22. 


\section{Chapter 4}

Aldhelm's De Virginitate was written and presented to a double monastery at a point in time that both the spiritual and political bases of the institution were being threatened. Theodore's arrival into Britain brought with it a set of teachings that were hostile to the double monastery. It is my contention that Aldhelm's De Virginitate represents a defense of the institution of the double monastery and a cooperative form of gender relations in the midst of this challenge to their orthodoxy. Aldhelm needed to maintain his own orthodoxy while defending the double monastery, as he was himself a member of the church hierarchy and would have been subject to the same pressures that Theodore was bringing to bear against the rest of the ecclesiastical body. Aldhelm has been sometimes held to approach the conflicting demands of tradition and his audience through a series of vague equivocations that diplomatically dance around the issue without ever explicitly dealing with it. ${ }^{226}$ While Aldhelm does tactfully make a serious attempt to stay within the interpretations held by Theodore, the result of his argument is a firm backing of chastity over virginity. The manner in which Aldhelm accomplished the negotiation between maintaining his own orthodoxy while defending that of the double monastery is the main focus of this chapter.

Aldhelm puts forward two main propositions in the De Virginitate. First, he argues that interior spirituality was more important than exterior purity which is primarily dealt with in the first and last sections of Aldhelm's three-part treatise. The second major theme of the De Virginitate is its depiction of men and women functioning in chaste

\footnotetext{
${ }^{226}$ Hollis, 81-2, 84.
} 
cooperative relationships. This is primarily contained within the middle section of the treatise, an anthology of saints. ${ }^{227}$ These two themes both served to support the theological position of the double monastery.

The De Virginitate seems to have been crafted to meet the needs of this audience. This is evident not only from the addressing of the letter to specific members of Barking at their request, ${ }^{228}$ but also in the content and presentation of the work. The structure of the work itself also is important for understanding Aldhelm's purpose. In the following chapter I will attempt to show the ways in which Aldhelm's arguments served to provide a theological basis for the double monastery.

Interior vs. Exterior

The framework developed by Aldhelm for the double monastery is based upon prioritizing inner purity over corporeal virginity. His tactic of opposing physiological virginity versus inner purity begins in the first sentence of the work. Aldhelm addresses his work to the "virgins of Christ" who are to be praised not only for their "bodily purity," which is achieved by many, but also for their "spiritual chastity," which is less common. ${ }^{229}$ This distinction between bodily and spiritual purity forms the core of Aldhelm's work. Through the course of the first section of the work Aldhelm lays out the

${ }^{227}$ De Virginitate XX-LVII

${ }^{228}$ De Virginitate 1. Hildilitahe, regularis disciplinae et monasticae converstionis magistrae, simulque Iustinae ac Cuthburgae nec non Osburgae, contribulibus necessitudum nexibis conglutinate, Aldgithae ac Scholasticae, Hidburgae et Berngithae, Eulaliae ac Teclae.

${ }^{229}$ De Virginitate Reverendissimis Christi virginibus omnique devotae germanitatis affectu venerandis, et non solum cororalis pudicitiae praeconio celebrandis, quod plurimorum est, verum etiam spiritualis castimoniae gratia glorificandis, quod paucorum est. 
basis for holding 'spiritual chastity' above 'bodily purity. ${ }^{, 230}$ While this theory makes sense in regards to his social situation and that of his audience, it is in contrast to the tradition in patristic sources of identifying physical virginity as the highest good. This tradition was by no means universal or an uncontested proposition. As has been noted, elements of both Augustinian and Gregorian thought often placed the spirit over the body in importance. Aldhelm is in the difficult spot of fitting his position into accordance with that of the traditional view that holds virginity above all else. The beginning of the work is an attempt by Aldhelm to reconcile the two positions.

Aldhelm begins to navigate his way through this dilemma by asserting his orthodoxy. Virginity is said to be obviously preferred to marriage as Jesus decided to enter the world through an uncontaminated virgin rather than the corrupted body of one married. ${ }^{231}$ However, even in this obvious statement of preference Aldhelm is quick to apologize to all those saints who were once married. Further, Aldhelm, while in the course of praising John the disciple for his virginity, also emphasizes that Christ is very enthusiastic about his love for chastity as well. ${ }^{232}$ Even though Aldhelm sees the need to conform to authoritative interpretations, he is simultaneously undermining their supremacy. He does this through a series of analogies based upon Pauline and Augustinian doctrine. Aldhelm uses this evidence to formulate an intellectual construction of gender for the double monastery of Barking that enables the previously married hierarchy of Barking to rule effectively even though they lack virginity.

${ }^{230}$ spiritualis castimonia ... corporalis pudicitae

${ }^{231}$ De Virginitate VII.1

${ }^{232}$ De Virginitate VII.2 
Aldhelm also emphasizes the dichotomy between the interioris and exterioris

hominis through metaphor. His use of a metaphor comparing the nun's scholarly activity to athletes is one such example. Aldhelm uses a very physical description of athletes to describe what he imagines is the women's academic pursuits of knowledge. He imagines them:

Growing learned in divine doctrine through the Church's maternal care, and like talented athletes under some experienced instructor training in the gymnasium through wrestling routines and gymnastic exercises ... sweating with the sinuous writhings of the flanks in the burning center of the wrestling pit. ${ }^{233}$

Aldhelm's construction of gender, in relation to the nun's at Barking, was less constrained than those often applied to women. ${ }^{234}$ By highlighting the extroverted role of Olympic athletes and soldiers, and then expressly linking this to the role of those who study, Aldhelm is clearly placing the nuns at Barking in the external sphere. This also figuratively relates to the role of the monks and nuns at Barking. Rather than seeing them as enclosed members of a segregated group, Aldhelm positions them as active and celebrated. Aldhelm's description of the nuns' active nature can be contrasted with the ways in which Bede chose to portray the women in the Historia Ecclesiastica where he consistently shows female monastics as private and enclosed. ${ }^{235}$ While Aethelhild is the

\footnotetext{
${ }^{233}$ De Virginitate II.1 velut sagaces gymnosophistas sub pertissimo quodam agonotheta palaestricis disciplines et gymnicis artibus in gymnasio exerceri. Qui laboriosi certaminis coronam et Olympiaci agonis triumphum, difficilliminis propriae exercitationis viribus naviter nanciscuntur. Ita duntaxat, ut alius stenua athletarum luctamina cum aemulo sinuosis laterum flexibus desudans, in meditullio scammatis fragrante delibutus lubrici liquoris nardo, solerter exercere studeat.

${ }^{234}$ This can be contrasted with Chrysostom's argument that men should behave like the proper masculine beings that they were lest they become feminine and attend to feminine concerns. "Christ wants us to be stalwart soldiers and athletes. He has not furnished us with spiritual weapons so that we take upon ourselves the service of girls worth only three obols, that we turn our attention to matters which concern wool and weaving and other tasks, that we spend all day having our souls stamped with women's habits and speech." Clark, "Instruction and Refutation Directed against Those Men Cohabitating with Virgins." ${ }^{235}$ Hollis, Anglo-Saxon Women and the Church, 244-270.
} 
only woman in the Historia to perform a miracle, she does so within the confines of her monastery. ${ }^{236}$ Similarly, Hild of Whitby rejects travel abroad and her influence is predicated on others visiting her. ${ }^{237}$

Aldhelm's text is consistent with what we know about the actual practice of monasticism in Northern Europe at this time. Rosamond McKitterick has shown that writing was not reserved for the male clerical elite and that there is a pattern of literate women who read, write and interpret texts. ${ }^{238}$ Indeed, the Boniface correspondence is full of examples that indicate women's literacy and production of texts. ${ }^{239}$ McKitterick summarizes this point by stating that "nun's scriptoria in the early Middle Ages, therefore, are not an isolated phenomenon, and the participation of women in the work of copying books was not exceptional., ${ }^{, 240}$ Aldhelm's description that equates the scholarly activity of the nuns with the active life of athletes and soldiers does not allow these activities to be understood as essentially masculine and is reminiscent of the matron martyr Perpetua. In her fourth vision while in prison she is led to the arena as a gladiator, where the pregnant woman transforms into a male and is rubbed with oil in the manner of a gladiator and athlete. ${ }^{241}$

\footnotetext{
${ }^{236}$ HE III. 11

${ }^{237} H E$ IV .23

${ }^{238}$ McKitterick, The Carolingians and the Written Word. "The Diffusion of Insular Culture in Neustria between 650 and 850: The Implications of the Manuscript Evidence" and "Women and Literacy in the Early Middle Ages," in Books, Scribes, and Learning in the Frankish Kigdoms, 6th-9th Centuries (Aldershot: Variorum, 1994), 1-43.

${ }^{239}$ Tangl, ed. Die Briefe des Heiligen Bonifatius und Lullus, 54, 60.

${ }^{240}$ McKitterick, "Women and Literacy in the Early Middle Ages," 22.

241 Sara Maitland, ed. The Martyrdom of Perpetua, ed. Monica Furlong, Visonary Women (Evesham: Arthur James, 1996), 26. See also Giselle de Nie, "'Consciousness Fecund through God:" from Male Fighter to Spiritual Bride-Mother in Late Antique Female Sanctity," in Sanctity and Motherhood: Essays on Holy Mothers in the Middle Ages, ed. Anneke Mulder-Bakker (New York: Garland Publishing, 1995), 116-123. Joyce Salisbury, Perpetua's Passion: The Death and Memory of a Young Roman Woman (New York: Routledge, 1997), 106-109. This passion is also the subject of a sermon by Augustine in which he argues that the spirit is neither male nor female. The omission of Perpetua from Aldhelm's work is rather
} 
The next goal of Aldhelm's text is to show the supremacy of chastity over virginity in practical terms. To do this, he modifies the Augustinian tripartite division of virgins, widows, and the married by replacing the widows with the chaste. This change is essential with respect to the members of his audience who were previously married and had left their husbands to pursue a monastic vocation. These women are clearly not widows yet he does not wish to categorize them according to their former state of marriage. To make this distinction Aldhelm relies upon the Augustinian tradition of the will being more important than the physical condition.

The concepts of virginity, corporeality and the external are contrasted with chastity, spirituality, and the internal. In essence, the corporality that functioned as the traditional distinction between virginity and marriage has linked them inseparably. While physical virginity uncorrupted by other sins is still superior to chastity, its inherent link to the external matter of the flesh, even if only by separation, puts its status in jeopardy. Focusing on the physical nature of the virgin state stresses the importance of the corporeal world over that of the spirit. Conversely, the internal focus of chastity and spiritual marriage places a higher value on the functioning of the soul. Taken in this context, Aldhelm's implication is that there can be little doubt as to which state should be preferred. Even though chastity holds an inferior rank to virginity in theory, its essentially spiritual nature makes it practically superior.

Aldhelm interpretation of St. Basil is a concise statement of this principal. He quotes Basil's maxim, "I do not know a woman, and yet I am not a virgin," which is not have had access to her vita seems likely. Lapidge and Herren, eds. Prose Works, 57. 
delivered to an audience of both sexes, as clear evidence for his argument. ${ }^{242}$ Aldhelm goes on to interpret that the:

stainlessness of bodily chastity - which is only external - was in no way suitable for acquiring the distinction of a vigorous integrity, unless chastity of the spirit, by whose command the untamed impulses of bodily wantonness are restrained - just as a servant-girl, lest she become stubbornly insolent, is subjected to the control of a mistress- inwardly cleaves to it harmoniously with comradely solidarity. ${ }^{243}$

Clearly, Aldhelm is restating his case regarding his call for spiritual purity instead of merely incorrupt flesh. However, the reference to the bernacula and the matrona are also of interest. Considering the repeated references to authority and control mentioned above, this passage would seem to represent a further statement of reaffirming the control of the abbess. It is not too difficult to imagine that this bernacula represents an unruly virgin nun who has been defying the authority of the abbess on the grounds that she is not a virgin who is put in her place by a strong matrona backed by the weight of Aldhelm's prose.

However, the central problem still exists for his audience in the double monastery as virginity is still to be held superior to their post-marital chastity. The answer Aldhelm provides revolves around the practical spiritual implications of virginity. Aldhelm argues that while the external purity of virginity is preferable, this state is spiritually susceptible to the contamination of pride. After a long section that spelled out the hierarchies of

\footnotetext{
${ }^{242}$ De Virginitate XXVII.2 et feminam non cognosco et virgo non sum.

${ }^{243}$ De Virginitate XXVII. 4 qui nequaquam extrinsecus carnalis tantum pudicitiae immunitatem ad promerendas strenuae integritatis infulas idoneam fore ratus est, nisi spiritus quoque castimonia, cuius imperio indomita corporalis lasciviae petulantia refrenatur, sicut bernacula, ne contumaciter insolescat, matronae nutibus mancipatur, intrinsecus contubernali soliditate concorditer adhaerescat
} 
virginity, chastity, and marriage, he laments that virginity often fails to fulfill its initial promise.
And yet --- unfortunately --- it usually occurs the other way around with the hierarchal positions reversed, so that the station of the inferior life, advancing on all fronts little by little, takes the place of the superior life as it languishes tepidly. ${ }^{244}$

Virginity's superior hierarchal position, attained by physical integrity, is lost through sloth and inaction that is caused by pride. This is contrasted to the action of one previously married, whose ignoble beginning is overcome through constant striving spurred on by bitter remorse. Aldhelm condemns "those of either sex who, inflated with the puffed-up arrogance of pride, exult in the integrity of flesh alone"245 further reinforces this construction with the analogy of boats passing Scylla and Charybdis. While the secure and untarnished ship of virginity does not attempt the passage, those who are chaste make the channel with their shaking vessel. ${ }^{246}$ Because of its humble beginnings, not in spite of them, chastity is able to overtake the formally superior rank of virginity.

Aldhelm does not wish to categorically deny that there are those virgins who are able to overcome pride. However, even this admission is couched in such a way as to reinforce the actual pre-eminence of chastity within the Barking nuns' social context. Aldhelm states that there are those who "from the very commencement of first infancy never cease from preserving indefatigably in the high pursuit of virginity" and are able

\footnotetext{
${ }^{244}$ De Virginitate X.1 Et tamen plerumque, pro dolor, immutatis ordinibus versa vice contingere solet, ut inferioris vitae gradus usquequaque paulatim proficiens superiorem tepide torpentem praeoccepet.

${ }_{245}^{24}$ De Virginitate X.1 in utroque sexu...qui tumido elationis supercilio inflati de sola carnis integritate gloriantur.

${ }^{246}$ De Virginitae X.1
} 
through constant self-recriminations to overcome the danger of pride. ${ }^{247}$ These individuals are only able to do this by removing themselves from society and engaging in a life of contemplation and sacrifice. Those living an active life could not match this sort of extraordinary holiness. ${ }^{248}$ Clearly, in this framework, the members of Barking were engaged in the active life of the minster and did not have the ability to live the life of a recluse. Aldhelm is stating that the only virgins who are of superior rank to the holy chaste are those who remove themselves from society. As this would not apply to members of Barking, any internal hierarchal issues between the virginal and the chaste would not be affected by this admission. But here again, the essential aspect of the recluse is not the external virginity, but the inner spirituality.

Virgins who do live in the active life must therefore guard their souls against the evil of pride. Using the Gospel parable of the ten virgins and Paul's first letter to the Corinthians, Aldhelm reinforces the point that bodily purity is not sufficient to obtain spiritual chastity. Not only is the body insufficient as a means for salvation, but it is actually a detriment that must be restrained. Citing Paul's struggle with his corporeal being we he exclaims, "I chastise my body and bring it into subjection," Aldhelm speaks of the need to scorn the freedom of the body by subjecting it to the yoke of legitimate servitude. ${ }^{249}$ By adapting Paul's body and spirit dichotomy, Aldhelm is able to apply it to the problematic nature of virginity.

Augustinian and Pauline thought was thus used to construct Aldhelm's own relationship between marriage and sexuality. Combining Paul's separation of the exterior

\footnotetext{
${ }^{247}$ De Virginitate XIV.1 ab ipso nacentis infantiae rudimento in summo virginitatis proposito infatigabiliter persevare non desistunt

${ }^{248}$ De Virginitate XIV.1

${ }^{249}$ De Virginitate XVI.6 Macero corpus meum, et servitutem redigo
} 
(body) and interior (spirit) with Augustine's division of sex and marriage, Aldhelm has put forward a syneisaktic formulation that imbued chaste individuals with the spiritual authority of virgins. This ranking of chastity is necessary in the context of a social situation that accepted the ability of members to leave marriage and enter holy life after beginning as active and influential members of society. Moreover, as their role within the minster system was anything but secluded and enclosed, these chaste members of the double monastery must be accounted for within the theology. Within this context, Aldhelm's adaptation of the tripartite division between virgins, widows and those married to include chastity serves a distinct need. Aldhelm elegantly incorporates the nuns at Barking into this framework by placing it into the context of the traditional system. ${ }^{250}$ Moreover, even at this point in his dialogue, Aldhelm feels the need to further undercut the status of virginity as the highest rank by suggesting that their position, according to certain authorities, might be better taken by martyrs:

To these three levels of rank, therefore, into which the flourishing multitude of believers in the catholic Church is divided, the gospel parable has promised hundred-fold, sixty-fold, and thirty-fold fruit according to the outlay of their merits, even though certain (authorities) are accustomed to allot the sheaves of the hundred-fold harvest, spouting abundantly in the fallow lands of the gospel and putting forth grain-bearing ears of corn, to the martyrs who pour out their holy blood in the manner of a stream for the Christian faith. ${ }^{251}$

\footnotetext{
${ }^{250}$ Hollis, 84.

${ }^{251}$ De Virginitate XIX.3 His igitur tribus gradum ordinibus, quibus credentium multitudo in catholica florens ecclesia discernitur, evangelium paradigma centesimum, sexagesimum et tricesimum fructum iuxta meritorum mercimonium spopondit, licet quidam centesimi fructus manipulos evangelicis novalibus ubertim pululantes et granigera spicarum glumula germinantes martiribus sacrum pro Christianae professionis titulo cruorem ritu rivi rorantibus deputare soleant.
} 
Aldhelm here refers to the well-established transition from actual martyrdom to the spiritual sacrifice of virginity. ${ }^{252}$ However, there is nothing absolutely physical about the donation of sexuality that would separate chastity from virginity. Furthermore, if Aldhelm's suggestion is that martyrs may actually deserve the highest rank, then this would seem to indicate a reordering of the hierarchy which delegitimated virginity's position as superior. Again, his point is to move the hierarchy of spiritual worth away from ones bodily state and towards that of inner spirituality.

While the first section focuses on making the case that chastity should be held superior to virginity, the final section is similarly devoted to attacking personal vanity among monastic men and women. This section begins with a long diatribe against ostentatious dress. ${ }^{253}$ This section is primarily drawn from Cyprian's De Habitu Virginum and Aldhelm picks up his language regarding the dress of women. Aldhelm quotes him in an address to virgins saying that:

[I] you dress yourself sumptuously and go out in public so as to attract notice, if you rivet the eyes of young men to you and draw the sighs of adolescents after you, and nourish the fires of sexual anticipation so that, even if you yourself do not perish, you nonetheless destroy others and present yourself to your onlookers as if you were poison or the sword, you cannot be excused as if you were of a chaste and modest mind. ${ }^{254}$

Aldhelm himself describes Judith as luring the "dreadful leader of the Assyrians" death through her "innate beauty" and "bodily adornment."256 He then emphasizes this

\footnotetext{
${ }^{252}$ e.g. Gregory's Homilae in Ezechielem II.8.16. Robert Markus, The End of Ancient Christianity (Cambridge: Cambridge University Press, 1990), 72.

${ }_{253}$ Chapters LV-LVIII.

${ }^{254}$ De Virginitate LVI. 6 si tu te sumptuosius comas et per publicam notabiliter incedas, oculos in te iuvenum illicias, suspiria adolescentium post te trahas, concupiscendi lunidinem nutrias, sperandi fomenta succendas, ut, etsi ipsa non pereas, alios tamen perdas et velut gladium te et venenum videntibus exhibeas, excusari non potes, quasi mente casta sis et pudica.

${ }_{255}$ De Virginitate LVII. 1 cum horrendum Assyriorum

${ }^{256}$ De Virginitate LVII.1 nativa vultus venustate ornanmetis etiam corporalibus
} 
by declaring, "You see, it is not by my assertion but by the statement of Scripture that the adornment of women is called the depredation of men!"257 These statements may seem out of character for the narrative that I have described above. Hollis sees these comments as representative of Aldhelm's view that women were a "morally dangerous force needing to be contained and marginalized."258 She attributes their existence to Aldhelm finally succumbing to the perceived misogyny of his environment. However, I would suggest that these remarks can be reconciled to the broader purpose of the narrative.

A better interpretation of this passage may be proposed if we merely trust the evidence. Immediately following his attack against ostentatious clothing, Aldhelm pulls back from the harsh nature of his stance by chastising himself for unnecessarily haranguing about garments, proclaiming that this tirade was directed at no one in particular, and that purity can only be found in the mind anyway. ${ }^{259}$ As Hollis has noted, Aldhelm has effectively argued away any substantial significance to the criticism against clothing. ${ }^{260}$

I would suggest that the section could only make sense if it is not viewed as a particular condemnation of practice, but rather as further evidence of the preference for the state of the interior soul over that of the exterior body. First of all, after extensive quotation of Cyprian, which would serve to solidify his orthodoxy, he immediate states that he is not really just referring to women in his condemnation of pretentious clothing. The beginning of chapter 58 in De Virginitate states that vanity is a concern for both

${ }^{257}$ De Virginitate LVII. 3 En, non nostris assertionibus sed scripturae a stipulationibus ornatus feminarum rapina virorum vocatur!

${ }^{258}$ Hollis, Anglo-Saxon Women and the Church, 104.

${ }^{259}$ De Virginitate LVIII. 8

${ }^{260}$ Hollis, Anglo-Saxon Women and the Church, 105-107. 
sexes. ${ }^{261}$ He goes on to make a detailed list of the excesses of male dress that includes the curling of hair, wearing intricate ribbons that fall to the feet, and sharpened fingernails suitable for an owl. Clearly, excessive ornamentation is not a strictly feminine concern.

Secondly, the choice of utilizing the story of Judith employs a narrative in which a heroine performs a noble act in spite of her use of excessive ornamentation. Aldhelm continues his pattern of presenting orthodox positions and then immediately critiquing them. Judith is presented as having committed this act while retaining her chastity and, "for that reason, having kept the honour of her modesty intact, she brought back a renowned trophy to her fearful fellow-citizens." ${ }^{262}$ This section simply does not make sense when viewed as a misogynistic diatribe. However, understood in light of Aldhelm's broader theme of comparing the interior world favorably to the external, the overall structure becomes apparent. The themes that Aldhelm develops through his use of saints lives can also be understood in this manner.

\section{$\underline{\text { Saints }}$}

Aldhelm's collection of fifty-seven saints is a self-described attempt at weaving together a crown of virginity favorable to Christ. ${ }^{263}$ The saints are divided between male

\footnotetext{
${ }^{261}$ De Virginitate LVIII. 1

${ }^{262}$ De Virginitate LVII.5 non casitatis defectu... idcirco, salva pudoris reverentia celebre meticulosis municipibus tropeum... reportavit.

${ }^{263}$ De Virginitate XX.1 Despite his earlier distinction regarding virginity and chastity in the immediately preceding chapters, he uses the term virginitas as if it was without the problematic nature that he assigned to it in theory. While Aldhelm's use of this term may be seen as further evidence of the random construction of the saints, I find this explanation unsatisfactory due to the precise nature of the text as a
} 
and female. Each section is presented in roughly chronological order with pre-Christian saints such as Elijah and David being followed by Apostles and then martyrs. Yet his representation of the saints is not merely a random listing of his sources. ${ }^{264}$ Rather, both the way in which the saints are presented and the overall structure of this section contribute to his argument.

Certain themes throughout his collection of saints seem to support Aldhelm's overall project of a spiritual companionship between men and women based on inner spirituality. The use of male and female saints furthers this argument in several ways. Once again, the mere inclusion of both male and female saints within the same collection figuratively embodies the reality of the double monastery. The double monastery is also represented through an emphasis on the scholarly nature of the saints. In light of Aldhelm's previous praise of the scholarly work at Barking and the obvious intelligence of their correspondence, it is not surprising that this would be a central issue.

Aldhelm goes to great pains to emphasize the internal spirituality of his exemplars and seeks to remove obstacles constructed by patristic tradition for an understanding of spiritual companionship. The predominance of internal spirituality is continued from his theological construction to his collection of saints. Aldhelm's sequencing of the

as a whole. Instead, I would suggest that perhaps Aldhelm sees the saints he refers to as virginal as implicitly representing those who are given it as a gift from God. For him sainthood itself may have been clear proof that the danger of pride had been avoided. Neither would the use of the term virgin necessarily undermine his argument regarding the problem of authority at Barking. If the suggestion that the crisis at Barking resulted from the questioning of the chaste authority at Barking, then under Aldhelm's framework one who wished to implicate his or her superior on the grounds of their own virginity would be forced into the sin of pride. Presumably, even the activation of a saintly exemplar for this purpose could lead one to this error. Alternatively, Aldhelm's inclusion of an alternative conceptualization of virginity may simply be a function of the florilegium style which Lapidge has suggested is the best way to understand the section on the saints. In this case, there is nothing incongruous about the inclusion of mutually contradictory elements in a single text.

${ }^{264}$ This is in contrast to Lapidge and Herren's characterization. Lapidge and Herren, eds. Prose Works, 57 58. 
development of chastity within his anthology is of critical importance. The figure of Jesus represents a turning point in the collection. Those saints which occur before Jesus are generally referred to as virginal while those after are generally chaste. The only exception to this trend in those saints coming before Christ is in the case of Daniel where he is described as both virginal and chaste. ${ }^{265}$ However, this need not be seen as breaking the trend as Daniel is well established as prefiguring Christ. Jesus himself is described as being the "author of all chastity" and as a virgin. ${ }^{266}$ The coming of Jesus brings about a renewed emphasis on the inner spirituality. There are those who are described as virgins following Jesus, but their virginity is characterized as a gift of grace, in Pauline fashion, instead of a human work. Ambrose's virginity is described as a praerogativam. This type of language is consistent with Aldhelm's earlier treatment of virginity. While it certainly has great value, it should be seen as something external to the individual and therefore of lesser importance in regards to their spiritual state.

Similarly relevant for his audience at Barking is the case of Constantina. As a daughter of the emperor who devoted herself to a religious life, she would have been a particularly resonant figure with the royal widows at Barking. Her exemplary appeal is still greater because she is presented as converting large numbers of women to leave their marriage beds for the glories of chastity. ${ }^{267}$ This significance of a strong royal woman who served as a missionary to her people would clearly not have been lost on Barking.

Within his narrative supporting the function of the double monastery Aldhelm continuously made every effort to remain orthodox. This is made all the more clear by

\footnotetext{
${ }^{265}$ De Virginitate XXI

${ }^{266}$ De Virginitate XXIII.1 totius castitatis auctorem

${ }^{267}$ De Virginitate XLVIII.1
} 
his inclusion of the lives of several saints that do not fit into his self imposed structure. Following his collection of female saints, Aldhelm inserted brief descriptions of the lives of Joseph, David, Samson, Abel and Melchisedech. This reversion to Old Testament saints at the end of his catalogue is problematic. Lapidge views this as another example of Aldhelm's randomness and can find no apparent reason for their placement here. In light of Aldhelm's dual needs to support the double monastery and remain within traditional views of authority, I believe I can explain their presence.

Much as the lives of the spiritual couples represented Aldhelm's views of the proper functioning of the double monastery, these Old Testament lives symbolize traditional authority and serve as a counterweight to any perceptions of his work as heterodox. The figures of David and Melchisedech show this to particular effect. The inclusion of David in a catalogue of virgins is really quite surprising considering his sexual history. Aldhelm explains David's suspect qualifications for virginity by explaining that he was "the most illustrious of kings" and was "endowed with a stainless virginity in boyhood of his youth before he was tied by the bond of matrimony and the shackle of marriage."268 The unhelpful revelation that David persevered in his virginity until married does not explain his presence in the treatise. However, Aldhelm's utilization of David in his traditional role as a symbol of monarchal power is much more compelling. Similarly, Melchisedech is described as embodying "the episcopal authority of heavenly power and the sacerdotal office of the divine priesthood" and is nowhere said

${ }^{268}$ De Virginitate LIII.4 David quoque opinatissimus regum sub ipso pubertatis tirocinio illibata vrginitate praeditus antequem copula matrimonii et conubii nexu nodaretur 
to even be a virgin. ${ }^{269}$ Obviously, David and Melchisedech were not added to the end of Aldhelm's catalogue of virgin saints because of their prominence as chaste exemplars. I would argue that they were put there to reinforce Aldhelm's respect for traditional sources of power and to balance his radical contentions.

\section{Spiritual Marriage}

Aldhelm followed a pattern in this anthology of saints that presented the male and female saints as functioning in a cooperative environment. The egalitarian relationship that Aldhelm suggests is akin to that of a marriage. Yet it is not that of physical marriage, but a spiritual marriage based on the unification of men and women in a religious cause. ${ }^{270}$ Aldhelm's justification for his interpretation begins in chapter eight immediately following the chapter recognizing virginity's supremacy through the incarnation of Jesus. Aldhelm extols the virtues of marriage and refers to the belittlement of marriage as the "ravings of heretics." 271 Yet the "flowers of virginity and the virtues of marriage"', are not the same after the coming of Christ. ${ }^{272}$ Referring to the Old Testament as a gloomy old document, Aldhelm is using patristic sources which saw the need for marriage receding after the coming of Christ and the new age as one of virginity. These passages alternately praised marriage as an institution yet disparages the need for it

\footnotetext{
${ }^{269}$ De Virginitate LIV.1 per Melchisidech vero supernae potestatis pontificum et caelestis infulae flaminium praesignabatur.

${ }_{270}$ The subject of chaste marriage throughout the medieval period is dealt with at length in Elliott, Spiritual Marriage. See also Hollis, Anglo-Saxon Women and the Church, 109-110.

${ }^{271}$ De Virginitate VII.1 schismaticorum deliramenta This argument shows Augustinian parallels regarding the De Bono Conjugali in which Augustine defended marriage in refutation of Jerome's earlier attack against marriage. Aldhelm certainly had knowledge of this text as he also alludes to it on at least two occasions. Ehwald, ed. Opera, 236 fn. 1, 246 fn 2, and 247 fn. 5.

${ }^{272}$ De Virginitate VII. 1 virginitatis flores et jugalitatis mores
} 
after Christ. This may be interpreted as simply Aldhelm dancing around a sticky issue by citing competing sources. However, I believe a better interpretation would be to see it as a prelude to his concept of the chaste marriage. The marriage condemned is the sexual marriage that can be held in opposition to virginity. If marriage is to be seen as good, yet the sexual necessity of it is removed, then what remains is a spiritual union.

The traditional attack against spiritual companionship between men and women came on the grounds that this was a dangerous and unnatural arrangement that could only lead to temptation and scandal. ${ }^{273}$ Aldhelm seems to have countered the assumption that men and women should be physically separated by repeatedly mentioning that the audiences to whom the saints were preaching were composed of either sex. Examples of this can be seen throughout the anthology on saints. ${ }^{274}$ By emphasizing the joint nature of men and women, Aldhelm is making a clear statement about the correct functioning of society. Aldhelm's model of a spiritual institution where men and women were working together was that of the spiritual marriage.

Of the fifty-seven saints that Aldhelm mentions, eight of them actually functioned within a chaste marriage and they are literally central to Aldhelm's argument. The section regarding males ends with six of the last seven saints operating within the framework of a spiritual union. Similarly, the second female saint discussed also is part of a chaste marriage. The only interruptions to this pattern are the lives of Apollonius and the Virgin Mary. Beginning the female saints with the Virgin Mary is dictated by Aldhelm's chronological presentation with which he organized the male saints and

\footnotetext{
${ }^{273}$ For example, see John Chrysostom's treatise against spiritual marriage Adversus eos qui subintroductas habent virgines.

${ }^{274}$ e.g. 10.1, 36.2.1, dispari sexu
} 
should not be viewed as a disruption to his design. ${ }^{275}$ Apollonius, on the other, cannot be explained away and seems to be an example of the capricious behavior that I am arguing against. However, despite this irregularity, the placing of so many examples of a chaste marriage within a narrative that extols the virtues of just such a model cannot be a coincidence. Rather, by centering chaste marriages within the design of his treatise, Aldhelm is emphasizing their importance. One other structural point to note here is the length of the stories about chaste marriages. On the whole, they are significantly longer than the average life included by Aldhelm. The successive examples of Chrysanthus and Daria followed by Julian and Basilissa are among the longest in the entire work. ${ }^{276}$ The space accorded to these lives is a further indication of their importance to the narrative.

The very first mention of a chaste marriage in De Virginitate occurs in the life of the apostle Thomas. He is said to have evangelized the eastern provinces of India and taught the practice of chaste partners in marriage. While Thomas is said to be praising virginity, he consistently refers to the integritas of the chaste marriage.

[W] hen he spoke for the instruction of chaste partners in marriage in the praises of virginity, said: 'You have integrity, which is the queen of all virtues and the fruit of perpetual virginity. Virginity is the sister of the angels and the possession of all good things; virginity is victory over desires, the trophy of faith, a triumph over enemies and the surety of eternal life.' See how the blast of the apostolic trumpet, blaring as if with the roar of thunder, urges the devout minds of virgins to the veneration of integrity, when it honors (integrity) with the mighty commendation of renown! $!^{277}$

${ }^{275}$ The lack of any female saints from the Old Testament is a curious omission from the text at this point and Aldhelm only includes the story of Judith near the end of his text. His treatment of the life of Judith will be discussed below.

${ }^{276}$ De Virginitate XXXV

${ }^{277}$ De Virginitate XXIII.8 cum pudicos thalami consortes intruens de virginitatis laudibus loqueretur, Habetis, inquit, integri tatem, quae est omnium regina virtutum et fructus perpetuae virginitatis. Virginitas soror est, angelorum et omnium bonorum possessio, virginitas victoria libidinum, tropeum fideim victoria de imicis et vitae aeternae securitas. En, apostolicae clangor bucinae velut tonitruali fragore concrepans 
The legitimacy of this teaching is reinforced through this link to apostolic tradition. Further, it is interesting to note that the particular source for Thomas' preaching of chaste marriage in India has not been able to be located by either of his modern editors. ${ }^{278}$ While it is not evidence that Aldhelm simply made this up, its apostolic placement is surely convenient for his argument.

The strongest examples for Aldhelm's advocacy of an institutional form of the chaste marriage can be shown through two examples from the text. The spiritual marriage of Chrysanthus and Daria is particularly relevant. Chrysanthus is a scholarly noble who had mastered all seven areas of classical education. Yet, once he had encountered the Gospel he rejected all earthly philosophy and refused his father's demands that he marry. After the father failed to change his son's mind through torture and imprisonment, he then tried to entice him back with the temptations of wine, feasts and willing virgins. Once again though, this vir Deo deditus, refused to succumb to the requirements and pleasures of the world. Finally, the father sends in the highly educated and beautiful vestal virgin Daria. Chrysanthus promptly converts Daria through reasoned debate and they live together in the form of a chaste marriage. Once together, they go out into the world preaching and convert a "great multitude of either sex."279

This story has several aspects which clearly support Aldhelm's narrative. First of all, Daria is portrayed as being every bit the equal of Chrysanthus with very similar language being used for both figures. The description of Chrysanthus' intellect is

devotas virginum mentes ad integritatis cultum cohortatur, dum eam immensis rumorum laudibus prosequitur.

${ }^{278}$ Ehwald, ed. Opera, 255. Lapidge and Herren, eds. Prose Works, 194-5.

${ }^{279}$ De Virginitate XXXV.11 quanta multitudo promiscui sexus. 
balanced by Daria being described as having been "so well trained in the dialectical arts and ... the sophistical procedures of the syllogism" that the "most eloquent orators" of her time feared to debate her. ${ }^{280}$ The conversion of Daria is then not a matter of superiority or command, but rather a prolonged "verbal debate and a reciprocal exchange of ideas" between relative equals. ${ }^{281}$ The length of the debate provides a further amount of respect for the Daria's character and capability. This description would resonate well with the highly educated women of Barking who worked with men in their monastic pursuits.

One of the other primary functions of Barking is also exemplified by this description. After creating this partnership, both begin preaching. The active and public nature of Chrysanthus and Daria's preaching tour is in no way delegitimated as we might expect. Rather, the companionship across gender is emphasized by the fact that their audience is specifically pointed out as being of both sexes. The ability of women and men to work together is not only seen as possible, but, in light of their prodigious number of coverts, desirable.

The lives of Julian and Basilissa show similar characteristics that support the application of the tradition of chaste marriages to the double monastery. Like Chrysanthus, Julian is shown as being pressured to marry by his family but resisting out of fear for his personal sanctity. Julian is, however, reassured by Christ in a vision that he should not fear marriage, where Jesus tells him: "For you shall take a wife who will

\footnotetext{
${ }^{280}$ De Virginitate XXXV.9 quod Daria dialecticis artibus imbuta et captionis sillogismi conclusionibus instructa fuisse ferebatur ita dumtaxat, ut disertissimi oratores tam sagax virginis instruca ingenium alterno experire conflictu vererentur.

${ }^{281}$ De Virginitate XXXV.10 Oritur namque inter eos satis prolixa sermonum concertatio et reciproca sententiarum disputatio.
} 
not separate you from me by fleshly pollution. ${ }^{, 282}$ He then marries Basilissa who Aldhelm presents as "lovely ... in her physical features but more beautiful inwardly through the adornment of her spiritual robes. ${ }^{, 283}$ And again, the couple goes out into the world and converts many "of either sex" and founds numerous monastic institutions. Once more the prominence of their spiritual union characterized by companionship and shared labor is seen to be both advantageous and profitable. This time, however, Christ himself supports the arrangement. Furthermore, the formula that describes their converts as being "of either sex" 284 is repeated. This phrase is also present in the subsequent account of the chaste marriage of Amos and his companion. The discussion of a marriage that is in fact enhanced by the lack of physicality fits well with the themes that Aldhelm seems to be developing in this section of the De Virginitate.

\section{Conclusion}

Evidence that men and women in the past were able to find a working relationship is often easy to dismiss. Attempts to explain away the institution of the double monastery are a particularly good example of this trend. Much of the motivation for these attacks seems to be that the patriarchal conceptions in the Christian tradition do not allow the relationship, yet we must question this assumption once evidence is found. Aldhelm's De Virginitate is just such evidence. Even the most authoritative texts could be manipulated by individuals for their own needs. While canonical texts such as the letters

\footnotetext{
${ }^{282}$ De Virginitate XXXVI.6 Accipies enim coniugem, quae te non polluendo a me separcet, sed per te virgo perseveret.

${ }^{283}$ De Virginitate XXXVI.7

${ }^{284}$ De Virginitate XXXVI.8 in utroque sexu.
} 
of Paul or the treatises of Augustine were indeed considered as the purveyors of unassailable orthodoxy, for these texts to maintain this position a large degree of latitude for interpreting these texts was necessary. ${ }^{285}$ Aldhelm's constructions were based upon these sources but utilized them to construct a model of cooperative relationships between men and women based upon internal values instead of a spiritual biological determinism.

Aldhelm was certainly not the only early medieval writer to argue for the prioritization of spirituality over physicality. One of the most likely inspirations for Aldhelm is Pope Gregory's writings concerning the acceptance of diversity within the church. ${ }^{286}$ Aldhelm particularly admired Gregory and he is described as:

the watchful shepherd and our teacher--- 'our' I say (because it was he) who took away from our forbearers the error of abominable paganism and granted them the rule of regenerative grace. ${ }^{287}$

Aldhelm was apparently quite familiar with Gregory's work and he is often cited by name in the De Virginitate. ${ }^{288}$ it is also worth noting that the extent to which the dangers of pride figure into Aldhelm's work is also reflected in Gregory's Homiliarum in Evangelia. $^{289}$ it is unclear to what extent Aldhelm may have been familiar with other examples of Gregory's writings. However, it seems likely, judging by the diffusion of Gregorian texts in Anglo-Saxon England and their influence personally on Aldhelm, that whatever of his works were available would have been included by Aldhelm. ${ }^{290}$ Even without a specific identification of texts available to Aldhelm, it may be worthwhile to

\footnotetext{
${ }^{285}$ Robert Markus, Signs and Meanings: World and Text in Ancient Christianity (Liverpool: Liverpool University Press, 1996), 9.

${ }^{286}$ See above, chapter 3 .

${ }^{287}$ De Virginitate LV.7 Unde Gregorius, pervigil pastor et pedagogus noster, --- noster inquam, qui nostris parentibus errorem tetrae gentilitatis abstulit et regenerantis gratiae normam tradidit.

${ }^{288}$ e.g. De Virginitate XII.1, XLII.1

${ }^{289}$ Homiliarum in Evangelia PL XL 4076-4314. see also, Carole Straw, "Gregory the Great," in Authors of the Middle Ages, Historical and Religious Writers of the Latin West (1996), 53.

${ }^{290}$ Ogilvy, Books Known to Anglo-Saxon Writers, 40-43.
} 
point out precedents for understanding gender differences in an egalitarian manner found in Gregory's homilies.

The wide variety of gender ideology found within Gregorian writings is an important example of how this egalitarian understanding could function. He might minimize the position of the women at Christ's tomb in one homily, only to highlight the position of an intellectual woman during the celebration of a male martyr. ${ }^{291}$ Gregory's use of gender models served to construct an intellectual framework that utilized both men and women as practical exemplars without relying upon the expected tropes of 'rational men' and 'emotional women., ${ }^{292}$ In doing so he "opened up the possibility of a radically egalitarian approach to gender and Christian practice., ${ }^{293}$ These examples show that Aldhelm's construction of an egalitarian framework was not an isolated case.

The efficacy of the personal model of a spiritual marriage that Aldhelm underscores was a very small step away from its application to the institution of the double monastery. The emphasis on the scholarly nature of both the male and the female, combined with their active and successful evangelizing, is too similar to the practice of the double monastery to be dismissed as coincidence. It seems clear that again Aldhelm has his audience firmly in view and was attempting to address their needs through the model of spiritual companionship. The focus upon the advantages that such an arrangement brings lends further credence to the institution which was under theological attack. By emphasizing the capabilities and equality of the women within the institution, he was fortifying it from both external assault and internal division.

\footnotetext{
${ }^{291}$ Lifshitz, "Gender and the Exemplarity East of the Middle Rhine: Jesus, Mary and the Saints in Manuscript Context."

${ }^{292}$ Lifshitz, "Gender and the Exemplarity East of the Middle Rhine," 8.

${ }^{293}$ Lifshitz, "Gender and the Exemplarity East of the Middle Rhine." 10.
} 


\section{Bibliography}

Abels, Richard. "The Council of Whitby a Study in Early Anglo-Saxon Politics." Journal of British Studies 23, no. 1 (1983): 1-25.

Arnold, C. J. An Archaeology of the Early Anglo-Saxon Kingdoms. London; New York: Routledge, 1997.

Atkinson, Clarissa. The Oldest Vocation: Christian Motherhood in the Middle Ages. Ithaca, New York: Cornell University Press, 1991.

Bateson, Mary. "The Origin and Early History of Double Monasteries." Transactions of the Royal Historical Society 13 (1899): 137-198.

Beall, Judith Lamm. "Bede and Irish Monasticism." Dissertation: University of California, Berkeley, 1997.

Bennett, Judith. "History That Stands Still: Women's Work in the European Past." Feminist Studies 14, no. 2 (1988): 269-283.

. "Feminism and History." Gender and History 1, no. 3 (1989): 251-272.

. "Confronting Continuity." Journal of Women's History 9, no. 3 (1997): 73-94.

Biddick, Kathleen. "Bede's Blush: Postcards from Bali, Bombay, Palo Alto." In The Shock of Medievalism, 82-101. Durham: Duke University Press, 1998.

Bischoff, Bernhard, and Michael Lapidge, eds. Biblical Commentaries from the Canterbury School of Theodore and Hadrian. Vol. 10, Cambridge Studies in Anglo-Saxon England. Cambridge: Cambridge University Press, 1994.

Blair, John. "St Frideswide Reconsidered." Oxoniensia 52 (1987): 71-127.

. "Minster Churches in the Landscape." In Anglo-Saxon Settlements, ed. Della Hooke, 35-58. Oxford: Oxford University Press, 1988.

. University of Oxford. Committee for Archaeology, and University of Oxford. Dept. for External Studies. Minsters and Parish Churches: The Local Church in Transition, 950-1200. Oxford: Oxford University Committee for Archaeology, 1988. 
. "Anglo-Saxon Minsters: A Topographical Review." In Pastoral Care before the Parish, ed. John and Richard Sharpe Blair, 226-66. Leicester; New York: Leicester University Press, 1992.

. "Debate: Ecclesiastical Organization and Pastoral Care in Anglo-Saxon England." Early Medieval Europe 4, no. 2 (1995): 193-212.

Blair, John and Carol Pyrah. Church Archaeology: Research Directions for the Future. York: Council for British Archaeology, 1996.

Blair, John, and Brian Golding. The Cloister and the World: Essays in Medieval History in Honour of Barbara Harvey. Oxford: Oxford University Press, 1996.

Blair, John, and Nigel Ramsay. English Medieval Industries: Craftsmen, Techniques, Products. London ; Rio Grande, OH: Hambledon Press, 1991.

Blair, John, and Richard Sharpe. Pastoral Care before the Parish Studies in the Early History of Britain. Leicester; New York: Leicester University Press, 1992.

Blair, Peter Hunter. An Introduction to Anglo-Saxon England. Cambridge: Cambridge University Press, 1977.

Blair, Peter Hunter, Pauline Clarke, and Michael Lapidge, eds. Anglo-Saxon Northumbria, Collected Studies; Cs192. London: Variorum Reprints, 1984.

Bonner, Gerald. Church and Faith in the Patristic Tradition: Augustine, Pelagianism, and Early Christian Northumbria. Aldershot, Hampshire, Great Britain; Brookfield, VT: Variorum, 1996.

Brock, Sebastian. "The Syriac Background." In Archbishop Theodore: Commemorative Studies on His Life and Influence, ed. Michael Lapidge, 30-53. Cambridge: Cambridge University Press, 1995.

Brown, Peter Robert Lamont. The Body and Society: Men, Women, and Sexual Renunciation in Early Christianity Lectures on the History of Religions; New Ser., No. 13. New York: Columbia University Press, 1988.

Butler, Judith. Gender Trouble: Feminism and the Subversion of Identity. New York, 1990.

Cambridge, Eric and David Rollason. "The Pastoral Organization of Anglo-Saxon Church: A Review of the 'Minster Hypothesis'." Early Medieval Europe 4, no. 1 (1995): 87-104. 
Campbell, James. "Bede II." In Essays in Anglo-Saxon History, 29-48. London; Ronceverte, W. Va.: Hambledon Press, 1986.

. "The First Century of Christianity in England." In Essays in Anglo-Saxon History, 49-69. London: Hambledon Press, 1986.

Campbell, James, Eric John, and Patrick Wormald. The Anglo-Saxons. Ithaca, N.Y.: Cornell University Press, 1982.

Carver, Marvin. The Age of Sutton Hoo: The Seventh Century in North-Western Europe. Woodbridge, Suffolk, UK; Rochester, NY: Boydell Press, 1992.

. Sutton Hoo: Burial Ground of Kings? Philadelphia: University of Pennsylvania Press, 1998.

Cavallo, Guglielmo. "Theodore of Tarsus and the Greek Culture of His Time." In Archbishop Theodore: Commemorative Studies on His Life and Influence, ed. Michael Lapidge, 54-67. Cambridge: Cambridge University Press, 1995.

Chadwick, Henry. "Theodore, the English Church and the Monothelete Controversy." In Archbishop Theodore: Commemorative Studies on His Life and Influence, ed. Michael Lapidge, 88-95. Cambridge: Cambridge University Press, 1995.

Clapham, Alfred. "The Benedictine Abbey of Barking: A Sketch of Its Architectural History and an Account of Recent Excavations on Its Site." Transactions of the Essex Archaeological Society 12, no. 69-89 (1913).

. "The Benedictine Abbey of Barking: A Sketch of Its Architectural History and an Account of Recent Excavations on Its Site." Transactions of the Essex Archaeological Society 12 (1913): 69-89.

Clark, Alice. Working Life of Women in the Seventeenth Century Reprints of Economic Classics. New York: A.M Kelley, 1968.

Clark, Elizabeth. "Instruction and Refutation Directed against Those Men Cohabitating with Virgins." In Jerome, Chrysostom, and Friends: Essays and Translations, 158-248. Toronto: Edwin Mellen Press, 1979.

"Adam's Only Companion: Augustine and the Early Christian Debate on Marriage." Recherches Augustiniennes 21 (1986): 139-162. 
. "Constraining the Body, Expanding the Text: The Exegesis of Divorce in the Later Latin Fathers." In The Limits of Ancient Christianity: Essays on Late Antique Thought and Culture in Honor of R. A. Markus, ed. William E. Klingshirm and Mark Vessey, 153-171. Ann Arbor: University of Michigan Press, 1999.

Clover, Carol. "Regardless of Sex: Men, Women, and Power in Early Northern Europe." Speculum 68, no. 2 (1993): 363-387.

Colgrave, Bertram and R.A.B. Mynors, eds. Bede's Ecclesiastical History of the English People. Oxford: Clarendon Press, 1969.

Cook, A.S. "Sources for the Biography of Aldhelm." Transactions of the Connecticut Academy of Arts and Sciences 28 (1927): 273-93.

Coulstock, Patricia. The Collegiate Church of Wimborne Minster. Woodbridge: Boydell, 1993.

Cramp, Rosemary. "Monastic Sites." In The Archaeology of Anglo-Saxon England, ed. David Wilson, 201-252. London: Methuen \& Co Ltd, 1976.

Cubitt, Catherine. "Wilfrid's 'Usurping Bishops': Episcopal Succession in Anglo-Saxon England, C. 600- C. 800." Northern History 25 (1989): 18-38.

. Anglo-Saxon Church Councils C. 650-C. 850 Studies in the Early History of Britain. London: Leicester University Press, 1995.

. "Virginity and Misogyny in Tenth and Eleventh Century England." Gender and History 12, no. 1 (2000): 1-32.

Damico, Helen and Alexandra Hennessey Olsen, ed. New Readings on Women in Old English Literature. Bloomington: Indiana University Press, 1990.

Davies, Wendy. "Clerics as Rulers: Some Implications of the Terminology of Ecclesiastical Authority in Early Medieval Ireland." In Latin and the Vernacular Languages in Early Medieval Britain, ed. Nicholas Brooks, 81-97. Leicester: Leicester University Press, 1982.

de Nie, Giselle. "'Consciousness Fecund through God:' from Male Fighter to Spiritual Bride-Mother in Late Antique Female Sanctity." In Sanctity and Motherhood: Essays on Holy Mothers in the Middle Ages, ed. Anneke Mulder-Bakker, 101161. New York: Garland Publishing, 1995. 
Deitrich, Sheila. "An Introduction to Women in Anglo-Saxon Society (C. 600-1066)." In The Women of England from Anglo-Saxon Times to the Present, ed. Barbara Kanner, 32-56. Hamden, Conn.: Archon, 1979.

Dockray-Miller, Mary. Motherhood and Mothering in Anglo-Saxon England The New Middle Ages, ed. Bonnie Wheeler. New York: St. Martin's Press, 2000.

Ehwald, Rudolf, ed. Aldhelmi Opera. Monumenta Germaniae Historica. Auctores antiquissimi; t. 15. Berlin: Weidmar, 1919.

Elkins, Sharon K. Holy Women of Twelfth-Century England Studies in Religion. Chapel Hill; London (England): University of North Carolina Press, 1988.

Elliott, Dyan. Spiritual Marriage: Sexual Abstinence in Medieval Wedlock. Princeton: Princeton University Press, 1993.

Elm, Susanna. Virgins of God: The Making of Asceticism in Late Antiquity. Oxford: Clarendon Press, 1994.

Evergates, Theodore "Aristocratic Women in the County of Champagne." In Aristocratic Women in Medieval France, ed. Theodore Evergates, 75-110. Philadelphia: University of Pennsylvania Press, 1999.

Fell, Christine E. Women in Anglo-Saxon England. London: British Museum Publications, 1984.

. "Some Implications of the Boniface Correspondence." In New Readings on Women in Old English Literature, ed. Helen Damico and Alexandra Hennessey Olsen, 29-43. Bloomington: Indiana University Press, 1990.

Finsterwalder, Paul. Die Canones Theodori Cantuariensis und ihre Überlieferungsformen. Weimar: Hermann Böhlaus Nachfolger G. m. b. H., 1929.

Foot, Sarah. "Anglo-Saxon Minsters: A Review of the Terminology." In Pastoral Care before the Parish, ed. John Blair and Richard Sharpe, 212-225. Leicester; New York: Leicester University Press, 1992.

. "The Role of the Minster in Earlier Anglo-Saxon Society." In Monasteries and Society in Medieval Britain: Proceedings of the 1994 Harlaxton Symposium, ed. Benjamin Thompson, VI, 35-58. Stamford: Paul Watkins, 1999.

. Veiled Women I: The Disappearance of Nuns from Anglo-Saxon England. Aldershot: Ashgate, 2000. 
Frantzen, Allen J. "The Tradition of Penitentials in Anglo-Saxon England." In AngloSaxon England, ed. Peter Clemoes, 11, 23-56. Cambridge: Cambridge University Press, 1983.

Gallyon, Margaret. The Early Church in Wessex and Mercia. Lavenham, Suffolk: T. Dalton, 1980.

Gamer, John and Helena McNeill, ed. Medieval Handbooks of Penance: A Translation of the Principal Libri Poenitentiales and Selections from Related Documents. New York: Columbia University Press, 1990.

Ganz, David. "Corbie and Neustrian Monastic Culture 661-849." In La Neustrie: Les Pays Au Nord De La Loire De 650-850, ed. Hartmut Atsma, 2, 339-347. Paris: Jan Thorbecke Verlag Sigmaringen, 1989.

Gilcrist, Roberta. Gender and Material Culture: The Archaeology of Religious Women. London: Routledge, 1994.

Godfrey, John. "The Place of the Double Monastery in the Anglo-Saxon Minster System." In Famulus Christi: Essays in Commemoration of the Thirteenth Centenary of the Birth of the Venerable Bede, ed. Gerald Bonner. London: SPCK, 1976.

Goffart, Walter. The Narrators of Barbarian History (A.D. 550-800): Jordanes, Gregory of Tours, Bede, and Paul the Deacon. Princeton: Princeton University Press, 1988.

Haddan, Arthur and William Stubbs, eds. Councils and Ecclesiastical Documents Relating to Great Britain and Ireland. Vol. III. Oxford, 1869-78.

Hanawalt, Barbara, ed. Women and Work in Preindustrial Europe. Bloomington: Indiana University Press, 1986.

Hen, Yitzhak, and Matthew Innes. The Uses of the Past in the Early Middle Ages. Cambridge: Cambridge University Press, 2000.

Herrin, Judith. The Formation of Christendom. Princeton, N.J.: Princeton University Press, 1987.

Hilpisch, Stephanus. Die Doppelklöster: Entstehung und Organisation. Münster in Westf: Aschendorff, 1928.

Hodges, Richard. The Anglo-Saxon Achievement: Archaeology \& the Beginnings of English Society. Ithaca, N.Y.: Cornell University Press, 1989. 
Hollis, Stephanie. Anglo-Saxon Women and the Church: Sharing a Common Fate. Woodbridge, Suffolk UK: Boydell Press, 1992. $41-64$.

. "The Minster-in-Thanet Foundation Story." Anglo-Saxon England 27 (1998):

Hooke, Della. The Landscape of Anglo-Saxon England. London; Washington: Leicester University Press, 1997.

Hunter, David. "Clerical Celibacy and the Veiling of Virgins: New Boundaries in Late Ancient Society." In The Limits of Ancient Christianity: Essays on Late Antique Thought and Culture in Honor of R. A. Markus, ed. R. A. Markus, William E. Klingshirn and Mark Vessey, 139-152. Ann Arbor: University of Michigan Press, 1999.

James, Montague Rhodes. Two Ancient English Scholars: St Aldhelm and William of Malmesbury. Glasgow: Jackson, Wylie \& co, 1931.

Johnson, Penelope. Equal in Monastic Profession: Religious Women in Medieval France. Chicago: University of Chicago Press, 1991.

Kelly, Susan. "Anglo-Saxon Lay Society and the Written Word." In The Uses of Literacy in Early Mediaeval Europe, ed. Rosamond McKitterick, 36-62. Cambridge England; New York: Cambridge University Press, 1990.

. "Eighth-Century Trading Privileges from Anglo-Saxon England." Early Medieval Europe 1 (1992): 3-28.

Kirby, D.P. "Bede's Historia Ecclesiastica Gentis Anglorum: Its Contemporary Setting." In Bede and His World, 2, 903-926. Aldershot: Variorum, 1992.

Kittell, Ellen, and Kurt Queller. "'Whether Man or Woman": Gender Inclusivity in the Town Ordinances of Medieval Douai." Journal of Medieval and Early Modern Studies 30, no. 1 (2000): 63-100.

Klinck, Anne. "Anglo-Saxon Women and the Law." Journal of Medieval History 8 (1982): 107-121.

Krüger, Paul, and Theodor Mommsen. Corpus Iuris Civilis. Dublin: Apud Weidmannos, 1970.

Lapidge, Michael. "The Study of Latin Texts: The Evidence of Latin Glosses." In Latin and the Vernacular Languages in Early Medieval Britain, ed. Nicholas Brooks, 99-141. Leicester: Leicester Universtiy Press, 1982. 
. "The School of Theodore and Hadrian." In Anglo-Saxon England, ed. Peter

Clemoes, 45-73. Cambridge: Cambridge University Press, 1986.

. Anglo-Saxon Litanies of the Saints. Woodbridge, Suffolk, UK; Rochester,

NY: Published for the Henry Bradshaw Society by the Boydell Press, 1991.

. Bede the Poet Jarrow Lecture; 1993. Jarrow, England: St. Paul's Church, 1993.

. Archbishop Theodore: Commemorative Studies on His Life and Influence

Cambridge Studies in Anglo-Saxon England; 11. Cambridge: Cambridge

University Press, 1995.

. "The Career of Archbishop Theodore." In Archbishop Theodore:

Commemorative Studies on His Life and Influence, ed. Michael Lapidge, 1-29.

Cambridge: Cambridge University Press, 1995.

Lapidge, Michael and Michael Herren, ed. Aldhelm: The Prose Works. Cambridge, 1979.

Lawrence, Clifford Hugh. Medieval Monasticism: Forms of Religious Life in Western Europe in the Middle Ages. 2 ed. London: Longman, 1989.

Lees, Clare and Gillian Overing. "Birthing Bishops and Fathering Poets: Bede, Hild and the Relations of Cultural Production." Exemplaria, (1994): 35-66.

Leyser, Henrietta. Medieval Women: A Social History of Women in England, 450-1500. 1st ed. New York: St. Martin's Press, 1995.

Lifshitz, Felice. The Norman Conquest of Pious Neustria: Historiographic Discourse and Saintly Relics, 684-1090. Toronto, Ontario: Pontifical Institute of Mediaeval Studies, 1995.

. "Is Mother Superior?: Towards a History of Feminine Amtscharisma." In Medieval Mothering, ed. John Carmi Parsons and Bonnie Wheeler, 117-138. New York and London: Garland Publishing, Inc., 1996.

. "The Politics of Historiography: The Memory of Bishops in Eleventh-Century Rouen." History and Memory 10 (1998): 119-137.

. "Gender and the Exemplarity East of the Middle Rhine: Jesus, Mary and the Saints in Manuscript Context." Early Medieval Europe 9, no. 3 (2000): 1-19.

. "Demonstrating Gun(T)Za:Women, Manuscripts, and the Question of Historical Proof." In Vom Nutzen des Schreibens, ed. Walter Pohl and Helmut Reinitz. Vienna, forthcoming. 
LoPrete, Kimberly. "Adela of Blois: Familial Alliances and Female Lordship." In Aristocratic Women in Medieval France, ed. Theodore Evergates, 8-43.

Philadelphia: University of Pennsylvania Press, 1999.

Macy, Gary. "The Ordination of Women in the Early Middle Ages." Theological Studies 61 (2000): 481-507.

Maitland, Sara, ed. The Martyrdom of Perpetua. Edited by Monica Furlong, Visonary Women. Evesham: Arthur James, 1996.

Markus, Robert. The End of Ancient Christianity. Cambridge: Cambridge University Press, 1990.

. Signs and Meanings: World and Text in Ancient Christianity. Liverpool: Liverpool University Press, 1996. 1997.

Gregory the Great and His World. Cambridge: Cambridge University Press,

Markus, Robert, William E. Klingshirn, and Mark Vessey. The Limits of Ancient Christianity: Essays on Late Antique Thought and Culture in Honor of R. A. Markus Recentiores. Ann Arbor: University of Michigan Press, 1999.

Mayr-Harting, Henry. The Coming of Christianity to England. New York: Schocken Books, 1972.

McKitterick, Rosamond. The Carolingians and the Written Word. Cambridge: Cambridge University Press, 1989.

. "The Diffusion of Insular Culture in Neustria between 650 and 850: The Implications of the Manuscript Evidence." In La Neustrie: Les Pays au Nord de la Loire de 650-850, ed. Hartmut Atsma, 2, 395-432. Paris: Jan Thorbecke Verlag Sigmaringen, 1989.

. The Uses of Literacy in Early Mediaeval Europe. Cambridge England; New York: Cambridge University Press, 1990.

. "Anglo-Saxon Missionaries in Germany: Reflections of the Manuscript Evidence." In Books, Scribes and Learning in the Frankish Kingdoms, 6th-9th Centuries, 292-329. Aldershot: Variorum, 1994.

"Women and Literacy in the Early Middle Ages." In Books, Scribes, and Learning in the Frankish Kingdoms, 6th-9th Centuries, 1-43. Aldershot: Variorum, 1994. 
McNamara, Jo Ann. Sisters in Arms: Catholic Nuns through Two Millennia. Cambridge: Harvard University Press, 1996.

Milovanovic-Barham, Celica. "Aldhelm's Enigmata and Byzantine Riddles." In AngloSaxon England, ed. Michael Lapidge, 22, 51-64. Cambridge: Cambridge University Press, 1993.

Myres, J. N. L. The English Settlements Oxford History of England; Oxford; Oxford University Press, 1986.

Nelson, Janet. "Queens as Jezebels: The Careers of Brunhild and Balthild in Merovingian History." In Medieval Women, ed. Derek Baker, 31-77. Oxford: Blackwell, 1970.

Nichols, John, and M. Thomas Shank. Medieval Religious Women Cistercian Studies Series; No. 71. Kalamazoo, MI: Cistercian Publications, 1984.

Nicholson, Joan. "Feminae Gloriosae: Women in the Age of Bede." In Medieval Women, ed. Derek Baker, 15-29. Oxford: Blackwell, 1970.

Noble, Thomas. "Rome in the Seventh Century." In Archbishop Theodore:

Commemorative Studies on His Life and Influence, ed. Michael Lapidge, 68-87. Cambridge: Cambridge University Press, 1995.

Offen, Karen. "A Comparative European Perspective: Comment on 'Confronting Continuity." Journal of Women's History 9, no. 3 (1997).

Ogilvy, J.D.A. Books Known to Anglo-Saxon Writers from Aldhelm to Alcuin (670-804). Cambridge: Medieval Academy of America, 1970.

Orchard, Andy. The Poetic Art of Aldhelm Cambridge Studies in Anglo-Saxon England ;

8. Cambridge, England; New York: Cambridge University Press, 1994.

Pagels, Elaine. Adam, Eve and the Serpent. New York: Random House, 1988.

Peyroux, Catherine. "Abbess and Cloister: Double Monasteries in the Early Medieval West." Dissertation, Princeton University, 1991.

Plummer, Charles, ed. Two of the Saxon Chronicles Parallel. Oxford: Clarendon, 1892.

, ed. Venerabilis Baedae Historiam Ecclesiasticam Gentis Anglorum:

Historiam Abbatum, Epistolam Ad Ecgberctum, Una Cum Historia Abbatum Auctore Anonymo, Ad Fidem Codicum Manuscritorum Denuo Recognovit. Vol. 1. Oxford: Oxford University Press, 1896. 
Ranft, Patricia. Women and the Religious Life in Premodern Europe. New York: St. Martin's Press, 1996.

Renoir, Alain. "Eve's I.Q. Rating: Two Sexist Views of Genesis B." In New Readings on Women in Old English Literature, ed. Helen Damico and Alexandra Hennessey Olsen, 262-272. Bloomington: Indiana University Press, 1990.

Reynolds, Susan. "What Do We Mean by 'Anglo-Saxon' and 'Anglo-Saxons'?" Journal of British Studies 24 (1985): 395-414.

Rollason, David. "The Ecclesiastical Context." In The Origins of the Midland Village, ed. H. Fox. Leicester, 1992.

. "Monasteries and Society in Medieval Northumbria." In Monasteries and Society in Medieval Britain: Proceedings of the 1999 Harlaxton Symposium, ed. Benjamin Thompson, 59-74. Stamford, Lincolnshire: P. Watkins, 1999.

Salisbury, Joyce. Perpetua's Passion: The Death and Memory of a Young Roman Woman. New York: Routledge, 1997.

Schine Gold, Penny. "Male/Female Cooperation: The Example of Fontevrault." In Medieval Religious Women, ed. John and Shank Nichols, M. Thomas, 151-168. Kalamazoo, MI: Cistercian Publications, 1984.

Scott, Joan. "Gender: A Useful Category of Historical Analysis." The American Historical Review 91, no. 5 (1986): 1053-1075.

Scott, Joan and Louise Tilly. Women, Work, and Family. New York: Methuen, 1987.

Sharpe, Richard. "Some Problems Concerning the Organization of the Church in Early Medieval Ireland." Peritia 3 (1984): 230-70.

Sims-Williams, Patrick. "St. Wilfrid and Two Charters Dated AD 676 and 680." Journal of Ecclesiastical History 39, 163-83. (1988).

Stafford, Pauline. Queens, Concubines, and Dowagers: The King's Wife in the Early Middle Ages. Athens, Ga.: University of Georgia Press, 1983.

. "Women and the Norman Conquest." Transactions of the Royal Historical Society 6, no. 4 (1994): 221-249.

. "Queens, Nunneries and Reforming Churchmen: Gender, Religious Status and Reform in Tenth and Eleventh Century England." Past and Present 163 (1999): 335 . 
Stenton, Doris Mary. The English Woman in History. London: George, Allen and Unwin Ltd, 1957.

Stenton, Frank. "The Historical Bearing of Place-Name Studies: The Place of Women in Anglo-Saxon Society." Transactions of the Royal Historical Society 25, no. 1 (1943): 1-13. . Anglo-Saxon England. 3d ed. Oxford Eng.: Clarendon Press, 1971.

Stenton, Frank, and Doris Mary Stenton. Preparatory to Anglo-Saxon England: Being the Collected Papers of Frank Merry Stenton; Edited by Doris Mary Stenton. Oxford: Clarendon Press, 1970.

Stevenson, Jane Barbra. "Theodore and the Laterculus Malalianus." In Archbishop Theodore: Commemorative Studies on His Llfe and Influence, ed. Michael Lapidge, 11, 204-221. Cambridge: Cambridge University Press, 1995.

Straw, Carole. "Gregory the Great." In Authors of the Middle Ages, IV, 1-55, 1996.

Swanton, Michael James. The Anglo-Saxon Chronicle. London: Dent, 1996.

Szarmach, Paul E. "Aelfric's Women Saints." In New Readings on Women in Old English Literature, ed. Helen Damico and Alexandra Hennessey Olsen, 146-157. Bloomington: Indiana University Press, 1990. . Holy Men and Holy Women: Old English Prose Saints' Lives and Their Contexts SUNY Series in Medieval Studies. Albany, N.Y.: State University of New York Press, 1996.

Szarmach, Paul E., and Virginia Darrow Oggins. Sources of Anglo-Saxon Culture Studies in Medieval Culture. 20. Kalamazoo, MI: Medieval Institute Publications Western Michigan University, 1986.

Szarmach, Paul E., Joel Thomas Rosenthal, and International Society of Anglo-Saxonists. Meeting. The Preservation and Transmission of Anglo-Saxon Culture: Selected Papers from the 1991 Meeting of the International Society of Anglo-Saxonists Studies in Medieval Culture; 40. Kalamazoo, Mich.: Medieval Institute Publications Western Michigan University, 1997.

Tangl, Michael, ed. Die Briefe des Heiligen Bonıfatius und Lullus. Vol. 1, Monumenta Germaniae Historica: Epistolae Selectae. Munich: Weidmann, 1989.

Thacker, Alan. "Monks, Preaching and Pastoral Care in Early Anglo-Saxon England." In Pastoral Care before the Parish, ed. John Blair and Richard Sharpe, 137-70. Leicester; New York: Leicester University Press, 1992. 
Thompson, Alexander. "The Ministry of Women: A Report by a Committee Appointed by His Grace, the Lord Archbishop of Canterbury with Appendices and Fifteen Collotype Illustrations." ed. Archbishop of Canterbury's Committee on the Ministry of Women, 145-164. London: Society for Promoting Christian Knowledge, 1919.

Varin, Pierre Joseph. "Mémoire Sur Les Causes De La Dissidence Entre L'église Romaine, Relativement À La Célébration De La Fête De Pâques." Mémoires présentés par divers savants a l'Académie de Inscriptions et Belles-Lettres 1, no. 5 (1858): 88-243.

Wemple, Suzanne Fonay. Women in Frankish Society: Marriage and the Cloister, 500 to 900. Philadelphia: University of Pennsylvania Press, 1981.

. "Sanctity and Power: The Dual Pursuit of Early Medieval Women." In Becoming Visible: Women in European History, ed. Claudia Koonz Renate Bridenthal, and Susan Stuard, 131-151. Boston: Houghton Mifflin Company, 1987.

Whitehurst Williams, Edith. "What's So New About the Sexual Revolution?: Some Comments on Anglo-Saxon Attitudes toward Sexuality in Women Based on Four Exeter Book Riddles." In New Readings on Women in Old English Literature, ed. Helen Damico and Alexandra Hennessey Olsen, 262-272. Bloomington: Indiana University Press, 1990.

Whitelock, Dorothy, ed. English Historical Documents C. 500-1042. London: Eyre and Spottiswoode, 1968.

Wildman, William Beauchamp. Life of S. Ealdhelm, First Bishop of Sherborne. London: Chapman \& Hall, 1905.

Winterbottom, Michael. "Aldhelm's Prose Style and Its Origins." Anglo-Saxon England, no. 6 (1977): 39-76.

Wood, Ian. The Merovingian North Sea Occasional Papers on Medieval Topics; 1. Alingsås, Sweden: Viktoria Bokförlag, 1983. 1994. .The Merovingian Kingdoms, 450-751. London and New York: Longman,

Wormald, Patrick. Bede and the Conversion of England: The Charter Evidence Jarrow Lecture; 1984. Jarrow, Durham: St. Paul's Church, 1984. 
Yorke, Barbara. Wessex in the Early Middle Ages Studies in the Early History of Britain. London; New York: Leicester University Press, 1995.

. Kings and Kingdoms of Early Anglo-Saxon England. London: Routledge, 1997. 